\section{OAK RIDGE NATIONAL LABORATORY}

MARTIN MARUETTA

\title{
The Effects of Utility DSM Programs on Electricity Costs and Prices
}

Eric Hirst

MARTIN MARIETTA ENERGY SYSTEMS, INC.

FOR THE UNITED STATES

DEPARTMENT OF ENERGY 
This report has been reproduced directly from the best available copy.

Available to DOE and DOE contractors from the Office of Scientific and Technical Information, P.O. Box 62, Oak Ridge, TN 37831; prices available from (615) 576-8401, FTS 626-8401.

Available to the public from the National Technical Information Service, U.S. Department of Commerce, 5285 Port Royal Rd., Springfield, VA 22161.

This report was prepared as an account of work sponsored by an agency of the United States Government. Neither the United States Government nor any agency thereof, nor any of their employees, makes any warranty, express or implied, or assumes any legal liability or responsibility for the accuracy, completeness, or usefulness of any information, apparatus, product, or process disclosed, or represents that its use would not infringe privately owned rights. Reference herein to any specific commercial product, process, or service by trade name, trademark, manufacturer, or otherwise, does not necessarily constitute or imply its endorsement, recommendation, or favoring by the United States Government or any agency thereot. The views and opinions of authors expressed herein do not necessarily state or reflect those of the United States Government or any agency thereof. 


\title{
THE EFFECTS OF UTILITY DSM PROGRAMS ON ELECTRICITY COSTS AND PRICES
}

\author{
ERIC HIRST
}

NOVEMBER 1991

Sponsored by

Office of Conservation and Renewable Energy

U.S. Department of Energy

OAK RIDGE NATIONAL LABORATORY

Oak Ridge, Tennessee 37831 managed by

MARTIN MARIETTA ENERGY SYSTEMS, INC. under contract No. DE-AC05-84-OR21400 for U.S. DEPARTMENT OF ENERGY 


\section{TABLE OF CONTENTS}

Page

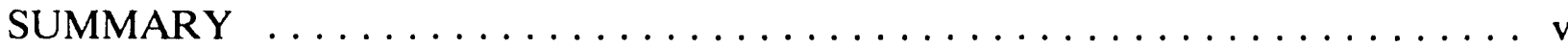

LIST OF ACRONYMS $\ldots \ldots \ldots \ldots \ldots \ldots \ldots \ldots \ldots \ldots \ldots$

1. INTRODUCTION $\ldots \ldots \ldots \ldots \ldots \ldots \ldots \ldots \ldots \ldots \ldots \ldots \ldots \ldots$

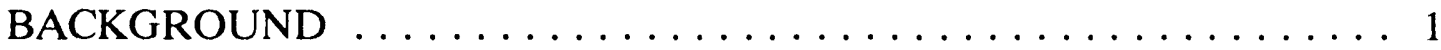

PURPOSE OF THIS STUDY $\ldots \ldots \ldots \ldots \ldots \ldots \ldots \ldots \ldots$

2. THE UTILITIES ANALYZED $\ldots \ldots \ldots \ldots \ldots \ldots \ldots \ldots \ldots \ldots$

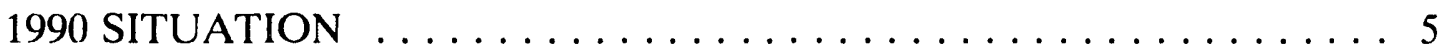

RESOURCE OPTIONS ..................... 8

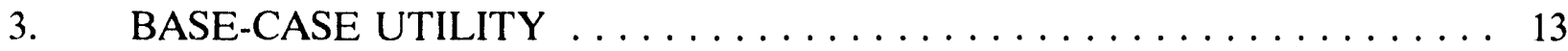

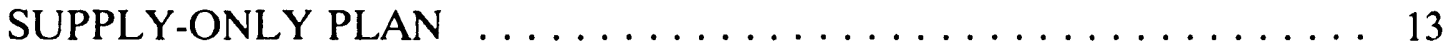

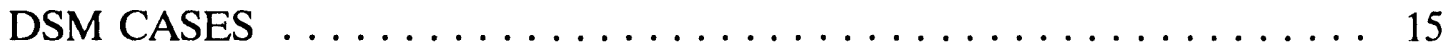

EXPENSING VS RATE-BASING DSM . . . . . . . . . . . 20

PURCHASE POWER VS CONSTRUCT POWER PLANTS . . . . . . 21

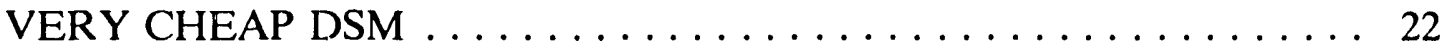

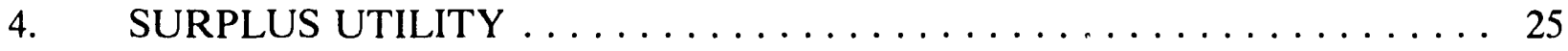

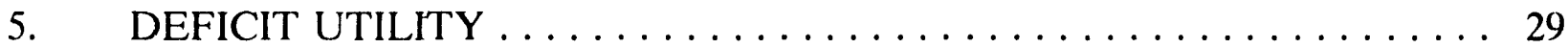

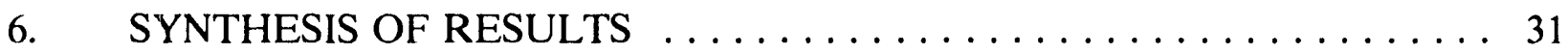

ACKNOWLEDGMENTS $\ldots \ldots \ldots \ldots \ldots \ldots \ldots \ldots \ldots \ldots \ldots \ldots \ldots$

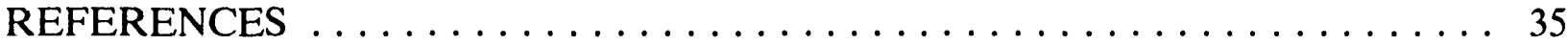

APPENDIX A: DIAMOND OUTPUTS FOR KEY CASES . . . . . . . . . . 39

APPENDIX B: DESCRIPTION OF THE DIAMOND MODEL . . . . . . . . 45

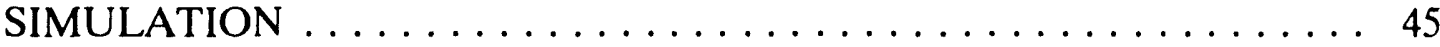

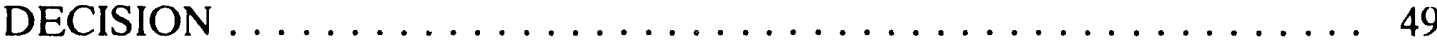




\section{SUMMARY}

More and more U.S. utilities are running more and larger demand-side management (DSM) programs. Assessing the cost-effectiveness of these programs raises difficult questions for utilities and their regulators. Should these programs aim to minimize the total cost of providing electric-energy services or should they minimize the price of electricity?

Most of the debates about the appropriate economic tests to use in assessing utility programs are philosophical and do not address the magnitude of the impacts. As a result, questions remain about the relationships among utility DSM programs and acquisition of supply resources and the effects of these choices on electricity prices and costs. If utilities run aggressive DSM programs, by how much will electricity prices rise, and over what time? If utilities minimize electricity prices, how much of a resource will be foregone that would have been cost effective if total costs were minimized?

This study does not resolve the philosophical debate over the proper role of electric utilities on the "customer side of the meter." It does offer quantitative estimates on the tradeoffs between total costs and electricity prices. This study uses a dynamic model to assess the effects of energy-efficiency programs on utility revenues, total resource costs, electricity prices, and electricity consumption for the period 1990 to 2010. These DSM programs are assessed under alternative scenarios. In these cases, fossil-fuel prices, load growth, the amount of excess capacity the utility has in 1990, planned retirements of power plants, the financial treatment of DSM programs, and the costs of energy-efficiency programs vary. These analyses are conducted for three utilities: a "base" that is typical of U.S. utilities; a "surplus" utility that has excess capacity, few planned retirements, and slow growth in fossil-fuel prices and incomes; and a "deficit" utility that has little excess capacity, many planned retirements, and rapid growth in fossil-fuel prices and incomes.

Figure S-1 illustrates the key findings from these simulations. They are:

- In general, DSM programs reduce electricity costs and raise electricity prices. Utilities and regulatory commissions must make tradeoffs between the total-resourcecost test and the rate-impact measure.

- Typically, the percentage reduction in electricity cost is much greater than the percentage increase in electricity price caused by DSM programs.

The financial treatment of DSM programs matters. Expensing DSM-program costs reduces program benefits by raising electricity prices in the short term. Capitalizing these costs defers the price increase for several years and reduces its size. 
- Even if DSM is very inexpensive or the utility faces very high avoided costs, the tradeoff between costs and prices remains. In special cases where the cost per $\mathrm{kWh}$ of DSM programs is very low, both prices and costs can be reduced.

- From the perspective of costs, DSM programs are cost effective even if the utility has excess capacity and slow load growth. This occurs because DSM programs offset not just the operating costs of existing plants, but also reduce the other costs of operating the utility system, defer construction of new transmission and distribution facilities, and, in the long term, defer the construction and operation of new power plants.

- The size of the tradeoff between costs and prices can be reduced by having customers share in the costs of the DSM measures installed by the program, by reducing the maximum cost of conserved electricity paid by the utility, or by delaying implementation of the program. However, these approaches also reduce the savings achieved by the programs, increasing the need for additional power supplies.

I recommend that utilities and regulators adopt a flexible approach to the assessment of DSM programs. Rather than adhering strictly to any single measure of cost effectiveness, they should work together to change program design and timing so that DSM programs provide major reductions in electric-energy-service costs with only minor increases in electricity prices.

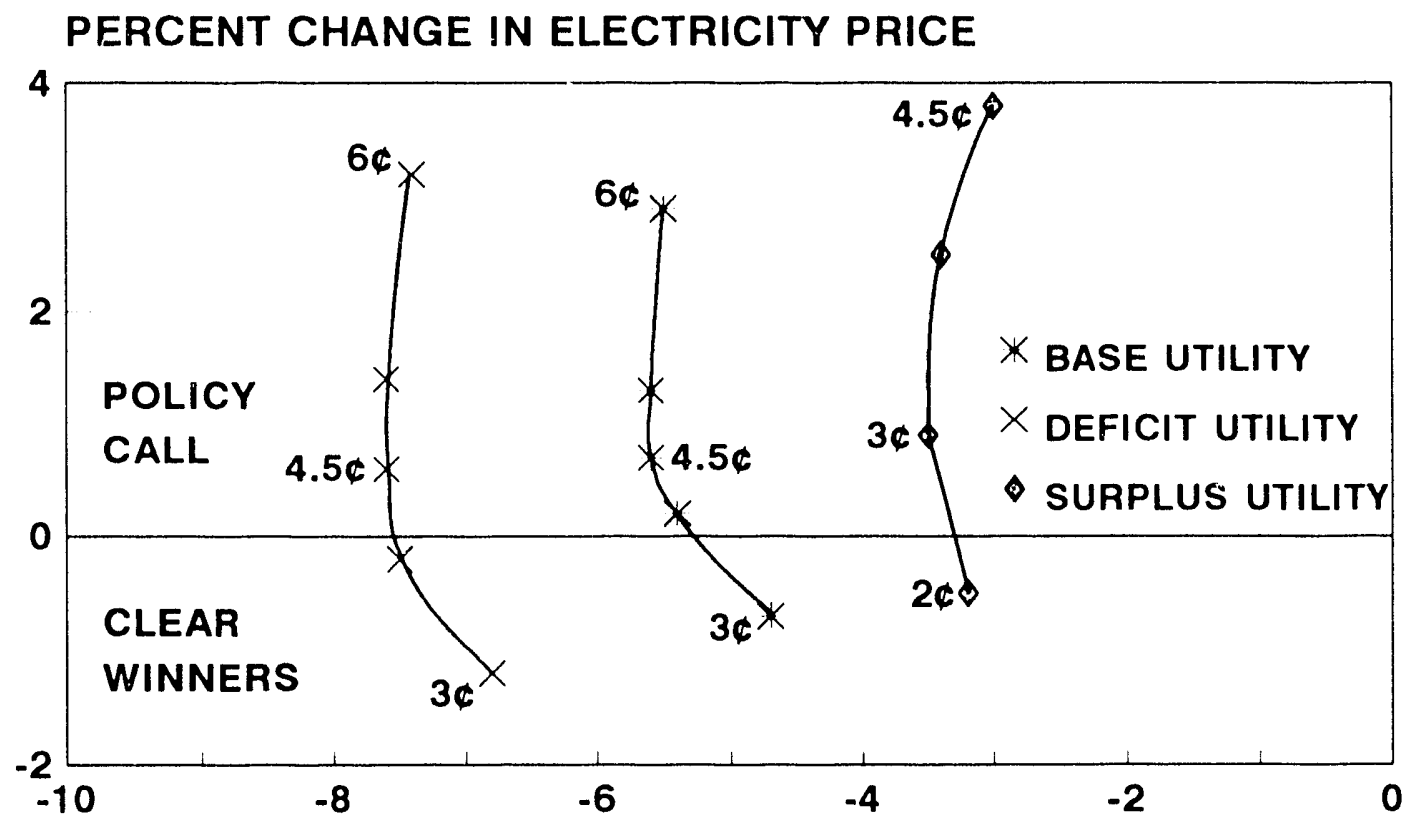

\section{PERCENT CHANGE IN REVENUE REQUIREMENTS}

Fig. S1. The effects of utility DSM programs on the net present value of utility revenues and average electricity price (1990 through 2010) for the base, surplus, and deficit utilities. The utility pays $100 \%$ of the costs of the DSM measures. The prices shown refer to the maximum cost of conserved electricity (in $\mathrm{c} / \mathrm{kWh}$ ) paid by the utility in its programs. 


\section{LIST OF ACRONYMS}

$\begin{array}{ll}\text { CCE } & \text { Cost of conserved electricity } \\ \text { DIAMOND } & \text { Decision Impact Assessment Model } \\ \text { DSM } & \text { Demand-side management } \\ \text { EIA } & \text { Energy Information Administration } \\ \text { NPV } & \text { Net present value } \\ \text { PUC } & \text { Public utility commission } \\ \text { RIM } & \text { Rate-impact measure } \\ \text { TRC } & \text { Total-resource-cost test }\end{array}$




\section{INTRODUCTION}

\section{BACKGROUND}

During the past several years, more and more electric utilities and their regulatory commissions have recognized the benefits of improving efficiency of electricity use (Faruqui tt al. 1990; Hirst 1991a). However, considerable controversy remains over the appropriate economic test(s) to use in assessing utility programs that increase customer energy efficiency and therefore reduce electricity use and utility revenues. People concerned about minimizing the total cost of electric-energy services favor the total-resource-cost test (TRC), while those concerned primarily about minimizing electricity prices favor the rate-impact measure (RIM); see Table 1.

Table 1. Elements of the key economics tests used to assess the benefits and costs of utility demand-side management (DSM) programs

\begin{tabular}{|c|c|c|}
\hline Perspective & Benefits & Costs \\
\hline $\begin{array}{l}\text { Rate-Impact } \\
\text { Measure }\end{array}$ & $\begin{array}{l}\text { Avoided supply costs } \\
\text { (production, transmission, and } \\
\text { distribution) based on energy } \\
\text { and load reductions }\end{array}$ & $\begin{array}{l}\text { Utility program costs, including } \\
\text { incentives to participants, plus } \\
\text { net lost revenue caused by } \\
\text { reduced sales }\end{array}$ \\
\hline $\begin{array}{l}\text { Total-Resource } \\
\text { Cost }^{a}\end{array}$ & $\begin{array}{l}\text { Avoided supply costs (same as } \\
\text { above) }\end{array}$ & $\begin{array}{l}\text { Total program costs to the } \\
\text { utility and participants (i.e., } \\
\text { measure costs plus utility } \\
\text { administrative costs) }\end{array}$ \\
\hline
\end{tabular}

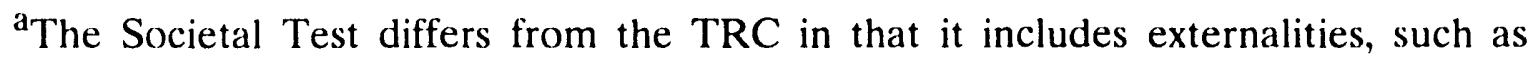
environmental costs and national security, in the estimation of benefits.

Source: California Public Utilities Commission and California Energy Commission (1987).

Most of the debates and discussions about the appropriate economic tests to use in assessing utility programs are philosophical and do not address the magnitude of the impacts. As a consequence, questions remain about the relationships among utility DSM programs and acquisition of supply resources and the effects of these choices on electricity prices and 
costs. If aggressive DSM programs are implemented, by how much will electricity prices rise, and over what time? If the RIM test is used, how much of a resource that would be cost effective under the TRC will be foregone? Most of the quantitative estimates that have been made of the tradeoffs between the RIM and TRC tests are based on the static equations developed by the California Public Utilities Commission and California Energy Commission (1987) or are for a particular utility under its baseline assumptions; see Krause and Eto (1988) for examples of these tests.

During the past few years, several public utility commissions (PUCs) (including those in Connecticut; Idaho; Illinois; Montana; Nevada; Washington, DC; and Wisconsin) have issued orders on the cost-effectiveness tests for DSM programs. These PUCs rejected use of the RIM test to screen DSM programs, relegated the RIM test to a secondary role, or mandated use of the TRC as the primary determinant of the cost effectiveness of utility DSM programs (Centolella 1991). The Massachusetts Department of Public Utilities (1988) ordered:

[L]ost revenues, to the extent they can be measured, are a transfer payment from the electric company to participants, rather than a cost of producing the end-use amenities for which customers seek electricity services. Accordingly, the lost revenues shouid not be counted in the analysis of a program's cost effectiveness.

The Maine PUC (1987) determined that a utility DSM program that:

is reasonably likely to satisfy the All Ratepayers Test [the TRC] is cost effective. ... Any program that is reasonably likely to satisfy the All Ratepayers Test and to fail the Rate Impact Test, but only to the extent that the utility's present value of revenue requirements per $\mathrm{kWh}$ do not increase by more than $1 \%$ over the duration of the program, may be continued or implemented without prior program specific Commission approval.

Others (Electricity Consumers Resource Council 1990) argue that utilities should aim to minimize electricity prices. Any other strategy would needlessly raise prices, encouraging electricity consumers to shift their energy needs to other fuels.

In a sense, the views of Massachusetts, Mane, and the Electricity Consumers Resource Council cover the spectrum. The Massachusetts statement endorses the TRC with no consideration of the RIM test. The Electricity Consumers Resource Council takes the opposite position. The Maine PUC adopted the TRC, tempered by consideration of the RIM test.

Some proponents of the RIM test (Ruff 1988) argue that it is economically inefficient for the utility to pay customers "twice" for energy-efficiency improvements. Utilities pay once through the direct cost of their programs (marketing and financial incentives to install energy-efficient devices); they pay a second time through the customer's reduction in his/her 
electricity bill. Ruff (1988) and Kahn (1991a and b) note that electricity prices send important signals to consumers and are the basis of a properly functioning market system. Providing additional incentives (beyond that allowed by the RIM test) to consumers to improve energy efficiency is equivalent to substituting the judgment of central planners in utilities and PUCs for the normal workings of the marketplace.

Others (Hirst 1989 and 1991b; Lovins 1989) argue that consumers in all sectors of the economy face many market barriers to improving energy efficiency. Thus, energy markets do not operate properly and require utility involvement. Utilities can help overcome these barriers and do so at low cost.

The reduction in customer electricity bills stimulated by utility DSM programs, often called lost revenues, is at the heart of the debate over the appropriate role of utilities in promoting energy efficiency. Some believe that the RIM test ensures that (1) markets are not tampered with needlessly and (2) nonparticipating ratepayers do not suffer because of utility DSM programs. Others believe that strict adherence to the RIM test ensures "no losers, but few winners" (Cavanagh 1986) and will increase the overall cost of electric-energy services.

The California Collaborative (1990), which included the state's major utilities, government agencies, environmental groups, consumer groups, and other organizations, reached partial consensus on the appropriate economic tests to use in assessing DSM programs:

Principle \#4: Defining Cost Effectiveness for Demand-Sice Resources ... DSM program cost effectiveness is defined by the Total Resource Cost (TRC) test. However, results of the TRC test alone do not determine the optimal level of DSM and associated program funding levels.

Principle \# 5: Two policy views on determining funding levels for demand-side resources were discussed. ... Each policy position recognizes that the determination of cost effectiveness for demand-side resource options is established by the TRC test. In both views, rate impacts are recognized as a relevant component of the decision process for setting funding levels. However, there are important differences on how to (1) integrate and balance rate impacts and their effects on [the utility's] competitive position, and (2) assess other attributes such as customer service levels and equity issues, in determining the level of demand-side activities that utilities ought to pursue .... .

Thus, the collaborative agreed that the TRC test was the primary determinant of the costeffectiveness of DSM programs. But the parties disagreed on the importance of the RIM test in program design and funding. 


\section{PURPOSE OF THIS STUDY}

While this report does not-indeed, cannot-resolve the philosophical debate over the proper role of electric utilities on the "customer side of the meter," it does offer quantitative estimates on the tradeoffs between total resource costs and electricity prices.

This report uses a dynamic model of an electric utility [Decision Impact Assessment Model (DIAMOND), described in Gettings, Hirst, and Yourstone 1991] to assess the effects of utility DSM programs on utiicy revenues, total resource costs, electricity prices, and electricity consumption. Results obtained with a dynamic model are likely to be more realistic than results obtained with a static model. This is so because a dynamic model captures the effects of different types of resources on future load growth, electricity prices, dispatch of power plants, and the financial status of the utility. While a static model requires, as inputs, assumptions about future avoided energy and capacity costs, dynamic models internalize these calculations.

DIAMOND is used to assess DSM programs under alternative scenarios that vary fossil-fuel prices, load growth, the amount of excess capacity the utility has in the initial year of the simulation (1990), planned retirements of existing power plants, the financial treatment of DSM programs, the fractions of supply resources obtained through utility construction of power plants vs purchase of power, and the costs of energy-efficiency programs. These analyses are conducted for the 1990-2010 period for three utilities:

- a "typical" U.S. utility, based on data and estimates from the Energy Information Administration (EIA 1989 and 1991);

- a "surplus" utility that has excess capacity, few planned retirements, and slow growth in fossil-fuel prices and incomes; and

- a "deficit" utility that has little excess capacity, many planned retirements, and rapid growth in fossil-fuel prices and incomes.

The following chapter describes the hypothetical utilities and their status as of 1990 . Chapters 3 through 5 present results from different cases run with the model. And Chapter 6 summarizes and synthesizes the findings from this study. Appendix A presents summary outputs from DIAMOND for the key cases discussed in Chapters 3 through 5. Appendix $B$ summarizes the key features of DIAMOND.

${ }^{*}$ A companion project examines different ways to integrate DSM programs with power plants into overall resource planning (Hill 1991). 


\section{THE UTILITIES ANALYZED}

\section{SITUATION}

I created three electric utilities with base, surplus, and deficit situations to reflect conditions with typical, low, and high avoided costs. These utilities were hypothesized from data on U.S. utilities (EIA 1989 and 1991). Information on these utilities was then fed into DIAMOND to assess the effects of DSM programs on electricity costs and prices when a utility faces different avoided costs.

For the year 1990, the base utility had $2275 \mathrm{MW}$ of generating capability, of which $48 \%$ was coal, 24\% nuclear, 19\% gas, and 9\% hydro (Fig. 1). Peak demand that year was $2000 \mathrm{MW}$ (including customer demand, $10 \%$ demand loss, and short-term on-peak sales), yielding a reserve margin of $14 \%$.

In 1990, the base utility generated $11,600 \mathrm{GWh}$ (including customer electricity use, $5 \%$ energy loss, and short-term off-peak sales). The system's load factor that year was $6.3 \%$. Coal provided $63 \%$ of the generation, nuclear $27 \%$, hydro $7 \%$, and natural gas $3 \%$ (Fig. 1 ). The utility's power plants produced electricity with a wide range in variable costs, from (0.3 to $4.5 \% / \mathrm{kWh}$ (Table 2). All costs and prices in this report are in constant 1990 dollars.

As of 1990 , the base utility had $710,0(00$ customers, an average retail electricity price of $6.5 \mathrm{c} / \mathrm{kWh}$, and revenues of $\$ 680$ million. Net income was $\$ 77$ million, equivalent to a $12.8 \%$ return on equity. The utility's rate base that year was $\$ 1.2$ billion.

Customer demand for electricity grows at an average rate of $2.0 \%$ year between 1990 and 2010. The utility will need new resources because of this projected load growth and because it will retire $600 \mathrm{MW}$ of existing generating units during the 2000s (Table 2). The utility expects to become deficit in 1995, and this deficit is projected to grow to almost 700 MW in the year 2000 and to $1400 \mathrm{MW}$ by 2010 (Fig. 2 and Table 3).

The surplus utility differs from the base utility in several ways (Table 3 ). The surplus utility has an additional $200 \mathrm{MW}$ of capacity in 1990, fewer customers and therefore lower demand, leading to a $27 \%$ reserve margin (instead of a $14 \%$ reserve margin). Because only $200 \mathrm{MW}$ of existing plants are scheduled for retirement and because its load growth is only $1.5 \%$ year, it needs only $400 \mathrm{MW}$ of new capacity during the two-decade period (compared with $1400 \mathrm{MW}$ for the base utility). Finally, both fossil-fuel prices and retail electricity prices are lower in 1990 and are expected to increase more slowly than for the base utility. The deficit utility, on the other hand, has greater retirement of existing plants, higher load growth, and higher fossil-fuel and electricity prices. 

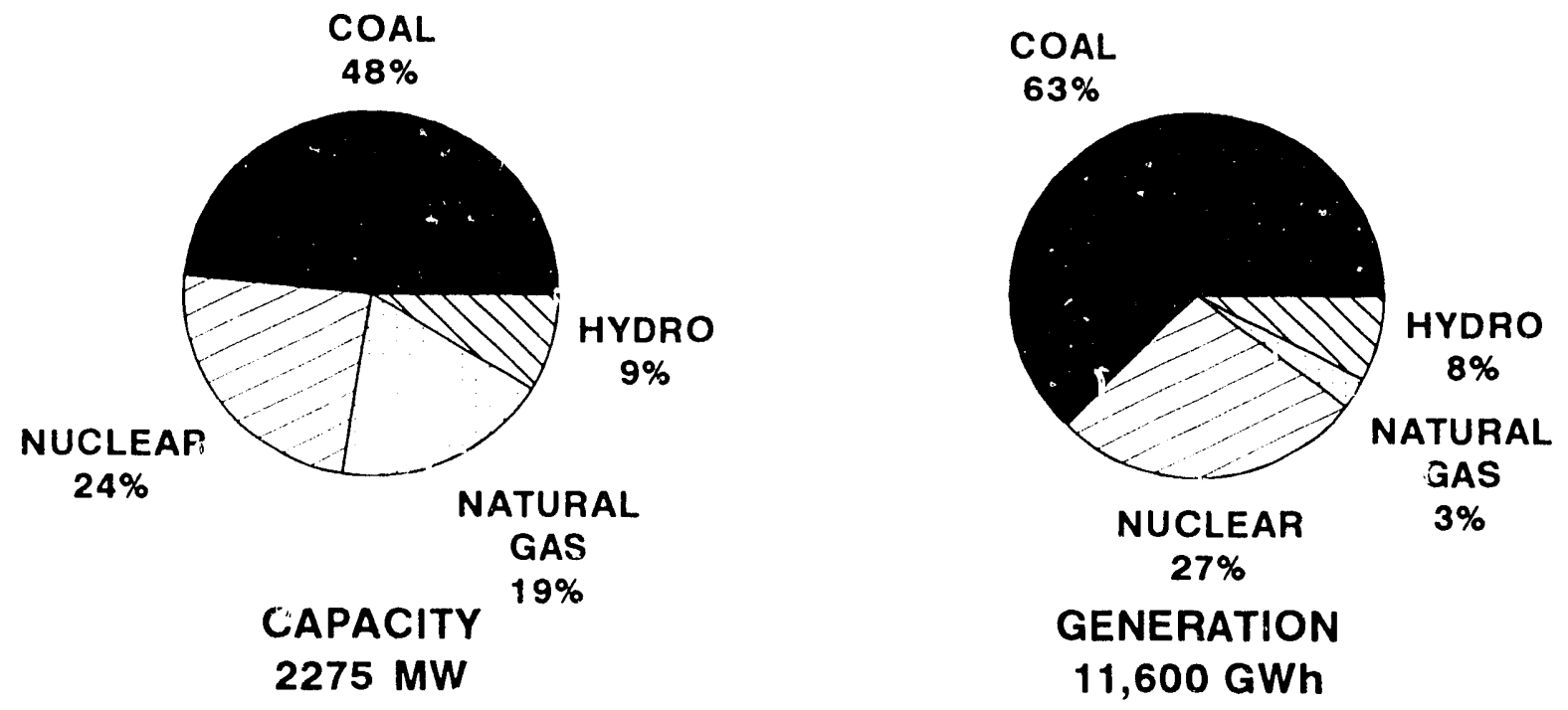

Fig. 1. Mix of fuels used by the base utility to provide capacity and energy in 1990.

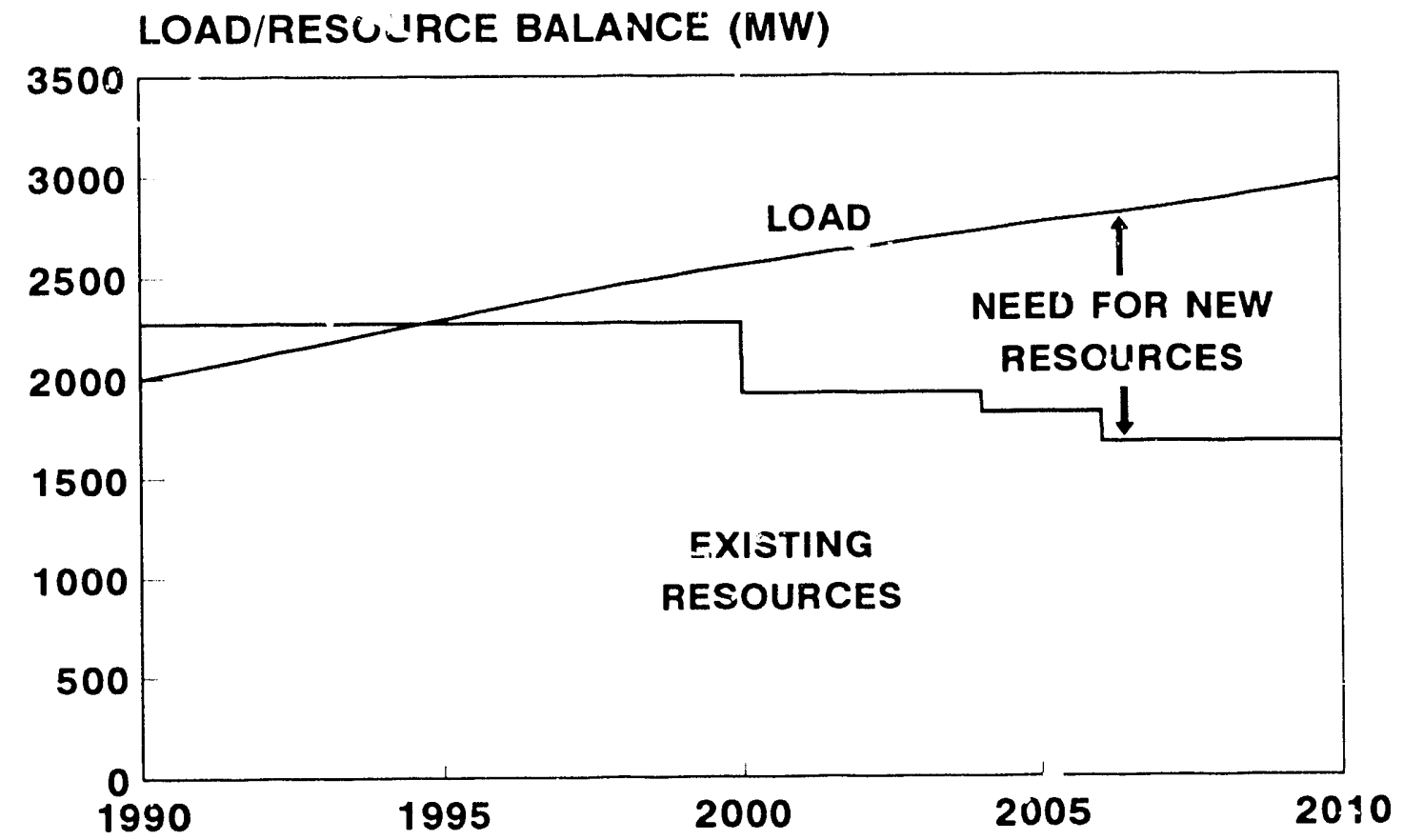

Fig. 2. Load/resource balance for the base utility showing peak demand and existing generating resources from 1990 to 2010. 
Table 2. Power plants in operation in 1990 for the base utility

\begin{tabular}{lccc}
\hline Type & $\begin{array}{c}\text { Size } \\
(\mathrm{MW})\end{array}$ & $\begin{array}{c}\text { Variable } \\
\text { cost, 1990 } \\
(1990-\mathrm{c} / \mathrm{kWh})\end{array}$ & $\begin{array}{c}\text { Offline } \\
\text { year }\end{array}$ \\
\hline Hydro & 50 & 0.3 & 2037 \\
Hydro & 150 & 0.3 & 2015 \\
Nuclear & 100 & 1.1 & 2004 \\
Nuclear & 450 & 1.1 & 2011 \\
Coal & 350 & 2.2 & 2000 \\
Coal & 500 & 2.3 & 2011 \\
Coal & 250 & 2.5 & 2013 \\
Combined cycle & 100 & 2.6 & 2018 \\
Combined cycle & 100 & 2.6 & 2018 \\
Combined cycle & 150 & 2.8 & 2006 \\
Combustion turbine & 75 & 4.5 & 2014 \\
\hline
\end{tabular}

Table 3. Comparison of situations facing the three utilities

\begin{tabular}{|c|c|c|c|}
\hline & Base & Surplus & Deficit \\
\hline Installed capacity in 1990 (MW) & 2275 & 2475 & 2275 \\
\hline 1990 reserve margin $(\%)$ & 14 & 27 & 14 \\
\hline \multicolumn{4}{|l|}{ Planned retirements } \\
\hline of power plants (MW) & 600 & 200 & 1100 \\
\hline \multicolumn{4}{|l|}{ Total resources added } \\
\hline from 1990 to $2010(\mathrm{MW})$ & 1400 & 400 & 1900 \\
\hline First year of deficit & 1995 & 2004 & 1995 \\
\hline Load growth (\%/year) & 2.0 & 1.5 & 2.4 \\
\hline \multicolumn{4}{|l|}{$\begin{array}{l}\text { Prices (1990 value, } \\
\% / \text { yr growth, 1990-2010) }\end{array}$} \\
\hline Natural gas & $3.123 .4 \%$ & $2.50 \quad 1.3 \%$ & $4.263 .8 \%$ \\
\hline Coal & $1.612 .0 \%$ & $1.24 \quad 1.1 \%$ & $1.962 .0 \%$ \\
\hline Retail electricity & $6.46 \quad 0.6 \%$ & $6.11-0.8 \%$ & $6.90 \quad 0.9 \%$ \\
\hline
\end{tabular}

${ }^{\text {a }}$ The 1990 prices paid by the utility for natural gas and coal are in \$/MBtu, while the price of electricity is in $\$ / \mathrm{kWh}$, in $1990-\$$. The growth rates are also in constant dollars. 


\section{RESOURCE OPTIONS}

For simplicity in the present analysis, utility-built power plants are limited to only a few choices: 500-MW coal, 200-MW coal, 100-MW combustion turbine, and 100-MW combined-cycle combustion turbine (Table 4). The construction and operating costs for these plants are based on estimates from the Electric Power Research Institute (1986) and the Michigan Department of Commerce (1987).

Environmental costs are based largely on the estimates reviewed by Koomey (1990), include $\mathrm{SO}_{2}$ and $\mathrm{NO}_{x}$, sometimes include $\mathrm{CO}_{2}$, but rarely include land and water impacts. The environmental costs for new power plants range from $0.9 \mathrm{c} / \mathrm{kWh}$ for combined-cycle units to $2.7 \mathrm{c} / \mathrm{kWh}$ for small coal plants. The environmental costs for existing plants are roughly double the costs for new plants. These costs are not used to make decisions about acquisition of new resources or about operation of existing power plants. They are computed only to show the environmental costs associated with different mixes of demand and supply resources.

Table 4. New power-plant options available to the utilities in this study

\begin{tabular}{|c|c|c|c|c|}
\hline & $\begin{array}{l}\text { Big } \\
\text { coal }\end{array}$ & $\begin{array}{l}\text { Small } \\
\text { coal }\end{array}$ & $\begin{array}{l}\text { Combustion } \\
\text { turbine }\end{array}$ & $\begin{array}{l}\text { Combined } \\
\text { cycle }\end{array}$ \\
\hline Plant size (MW) & 500 & 200 & 100 & 100 \\
\hline Availability $(\%)$ & 75 & 77 & 85 & 85 \\
\hline \multicolumn{5}{|l|}{ Operations \& maintenance } \\
\hline Fixed $(1990-\$ / k W)$ & 27.3 & 49.6 & 1.5 & 12.4 \\
\hline Variable (1990-c/kWh) & 0.5 & 0.6 & 0.5 & 0.1 \\
\hline Environmental cost $(1990-\mathrm{c} / \mathrm{kWh})$ & 2.5 & 2.7 & 1.2 & 0.9 \\
\hline Heat rate $(\mathrm{Btu} / \mathrm{kWh})$ & 10,000 & 11,000 & $12,00()$ & $8,(0) 00$ \\
\hline Fuel type & coal & coal & gas & gas \\
\hline Plant cost $(1990-\$ / k W)$ & 1140 & 1240 & 430 & 740 \\
\hline Years to construct & 10 & 9 & 4 & 5 \\
\hline Plant life (years) & 40 & 40 & 30 & 30 \\
\hline
\end{tabular}

The utility can also purchase power under long-term contracts from other utilities. These contracts cover either peaking power or offpeak power with prices based on the costs of the power plants shown in Table 4 . The primary difference between utility construction of power plants and purchase of power is that purchasing power has no effect on the utility's rate base because these purchases are treated as expenses.

Finally, the utility can choose to run DSM programs. Because the utility has only one customer class, only two types of DSM are practical, one aimed at new customers and one 
at existing customers. The lifetime of program-induced conservation extends beyond the analysis horizon.

Conservation-program performance depends on two factors: participation in the program and the net energy savings of the program. DSM-program cost-effectiveness depends on the energy savings and the utility's cost to run the program.

The utility's cost has three components:

1. A fixed charge (\$/year) that reflects the overall planning, design, and administration of the program

2. A marketing charge (\$/participant) that reflects the utility's cost to get customers to participate in the program

3. An acquisition charge $(c / \mathrm{kWh})$ that reflects the financial incentive paid by the utility for the materials and installation needed to acquire the conservation resource

Participation in the utility's conservation program follows a logistic curve over time; see Fig. 3. The slope of these curves is a function of the utility's marketing expenses and of its financial incentive, the second and third components of the utility's cost noted above.

Energy savings are computed on the basis of a conservation supply curve, which shows the potential electricity savings per participant as a function of the marginal levelized cost of conserved electricity (CCE, in $\mathrm{c} / \mathrm{kWh}$ ); see Fig. 4. This supply curve shows the relationship between the potential electricity savings and its cost for a typical (not yet participating) customer. These programs are assumed to have the same load factor as that of the utility system (63\%). Thus, a program that cuts consumption per participant by 5000 $\mathrm{kWh}$ also cuts peak demand by $0.91 \mathrm{~kW}$. The effects of market forces in improving electricity efficiency are assumed to offset technological developments each year so that the same supply curves apply each year for the utility's DSM programs.

To simplify comparisons across cases, the utility pays $100 \%$ of the DSM-measure costs in all programs (i.e., there is no customer contribution to these costs). This represents a worst-case scenario in terms of the RIM test. $\Gamma$ o the extent that customers share the cost of purchasing and installing DSM measures, the adverse rate impacts of DSM programs are reduced.

${ }^{*}$ This assumption is less drastic than it seems. Because existing customers retire at a rate of $1 \% /$ year, the energy savings from the program aimed at existing customers has the same attrition. Also, because the programs take several years to ramp up, the average lifetime of the savings is 10 to 15 years in this analysis. 


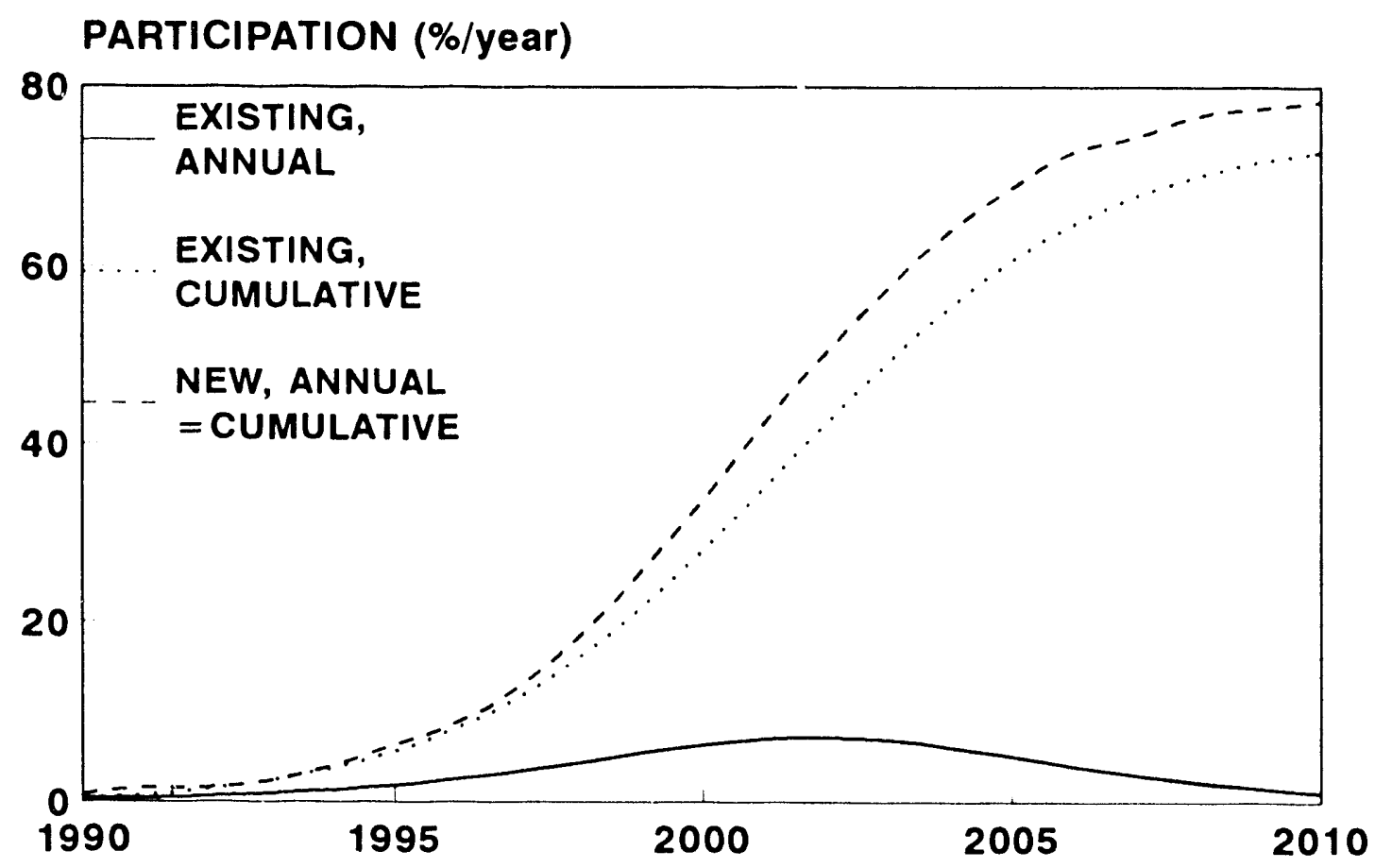

Fig. 3. Logistic curves showing annual anc cumulative participation rates over time in utility programs aimed at new and existing customers for the base utility.

POTENTIAL (kWh/participant)

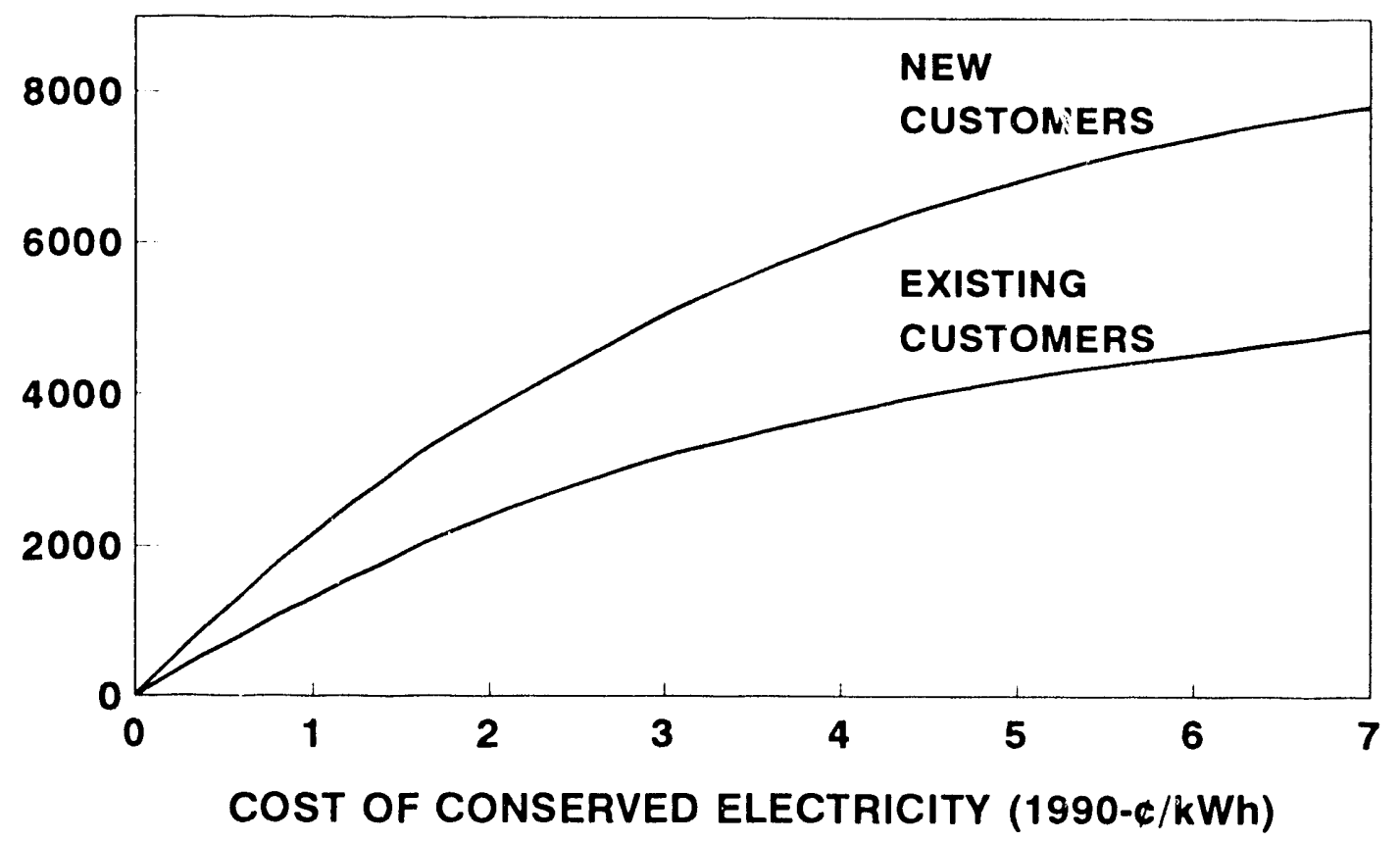

Fig. 4. Conservation supply curves showing amounts of saved electricity available as a function of CCE. These savings reduce demand at the time of system peak with a load factor of $63 \%$. The utility specification of ceiling price and fractional financial incentive determines how much of the savings is obtained. 
All the utility's capital costs, both supply and demand, are included in the rate base. In other words, the utility's DSM programs are capitalized, not expensed. The costs of DSM programs are depreciated over 15 years, investments in transmission and distribution are depreciated over 20 years, other investments (e.g., computers and office buildings) over 7 years, and power plants over the lifetime of the plant (ranging from 30 years for combustion turbines to 40 years for coal plants).

For these analyses, the utility maintains a balancing account to ensure that any variations between actual and forecast sales do not affect the utilicy's rate of return. This system is similar to the Electric Revenue Adjustment Mechanism used in California (Marnay and Comnes 1990) plus a fuel-adjustment clause. This mechanism ensures that utility shareholders are not penalized because DSM programs reduce electricity use. 


\section{BASE-CASE UTILITY}

\section{SUPPLY-ONLY PLAN}

I begin the analysis of the base utility by developing a supply-only plan. This plan is then used as the reference against which to compare plans that include DSM programs. Growth between 1990 and 2010 in income; retail gas price; and prices to the utility for gas, coal, and nuclear fuels are the same for all the cases discussed in this chapter (Table 3 ).

This supply-only plan is the one, among many alternatives tested, that yields the lowest net present value (NPV) of revenue requirements for the 1990-2010 period. " The alternatives tested include construction of different types and numbers of power plants, started at various dates between 1990 and 2000.

This plan includes a combination of coal- and gas-fired power plants (Table 5), with additions that total $1400 \mathrm{MW}$ between 1994 and 2008. Figure 5 shows the load/resource balance for this supply-only plan, and Table 6 presents summary statistics for this plan.

Table 5. Resources chosen in supply-only case for the base utility

\begin{tabular}{lcc}
\hline $\begin{array}{l}\text { Plant size } \\
\text { and type }\end{array}$ & $\begin{array}{c}\text { Start } \\
\text { date }\end{array}$ & $\begin{array}{c}\text { Online } \\
\text { date }\end{array}$ \\
\hline $200-M W$ coal & 1990 & 2000 \\
$100-\mathrm{MW}$ combustion turbine & 1992 & 1996 \\
100-MW combustion turbine & 1994 & 1998 \\
100-MW combustion turbine & 1994 & 1998 \\
200-MW coal & 1996 & 2005 \\
$100-\mathrm{MW}$ combustion turbine & 1996 & 2000 \\
200-MW coal & 1998 & 2007 \\
100-MW combustion turbine & 1998 & 2002 \\
200-MW coal & 2000 & 2009 \\
$100-\mathrm{MW}$ combustion turbine & 2000 & 2004 \\
\hline
\end{tabular}

*All costs and prices are in 1990 dollars. Calculations of net present value use the utility cost of money, roughly $10.5 \%$ in nominal terms and $6 \%$ in real terms. 
LOAD/RESOURCE BALANCE (MW)

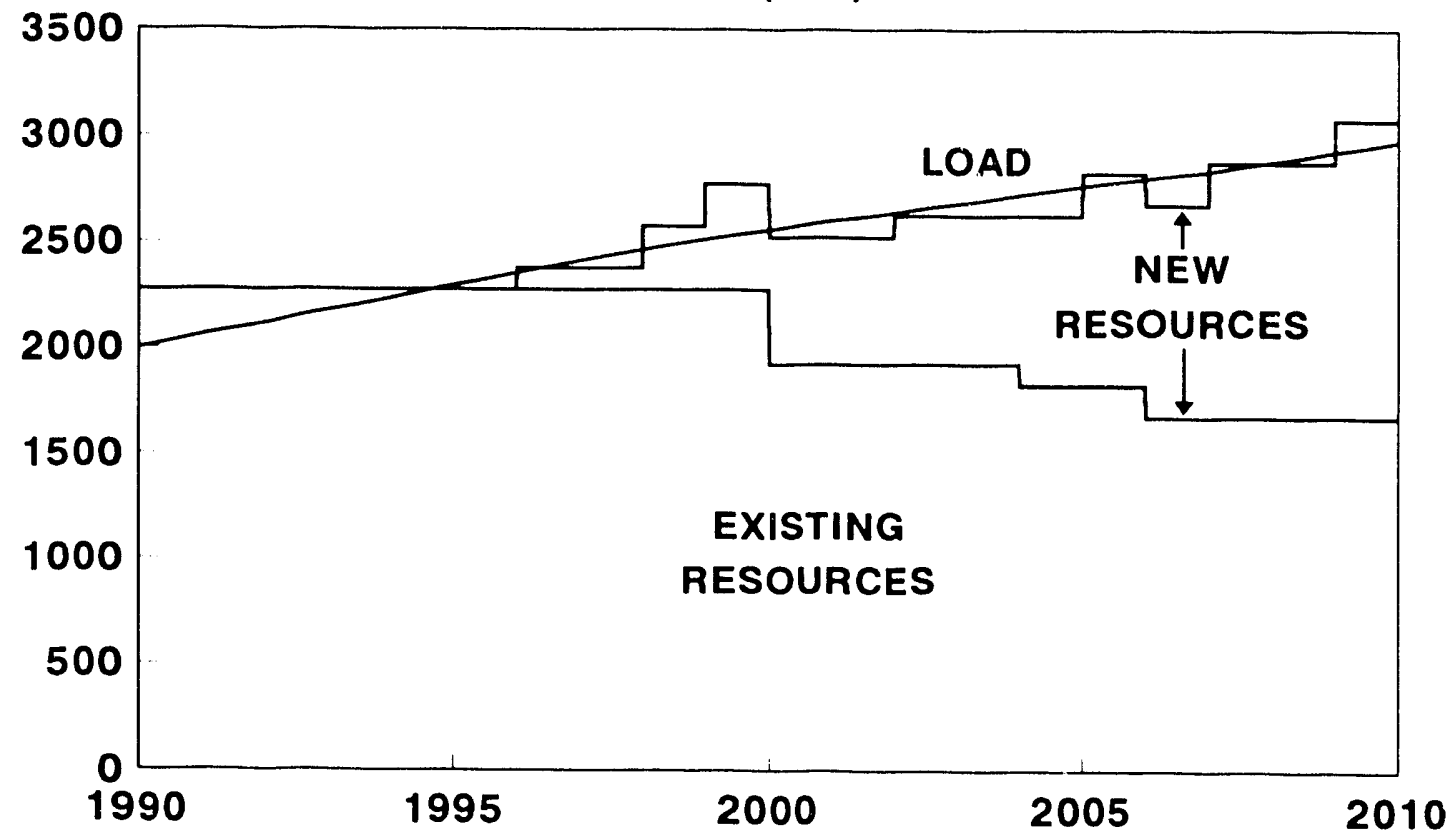

Fig. 5. Load/resource balance showing peak load, existing resources, and new power plants in the optimal supply case for the base utility.

Table 6. Summary of results for supply-only plan for the base utility

\begin{tabular}{lrc}
\hline & 1990 & $\begin{array}{c}\text { Average growth } \\
\text { rate, 1990-2010 } \\
\text { (\%/year) }\end{array}$ \\
\hline Number of customers (thousands) & 710 & 0.8 \\
Total electricity use (GWh/year) & 10.5 & 2.0 \\
Electricity price (c/kWh) & 6.46 & 0.6 \\
Average electric bill (\$/customer) & 960 & 1.9 \\
Utility revenues (million-\$) & 680 & \\
Utility assets (million-\$) & 1205 & \\
& & \\
Summary statistics, 1990-2010 & & \\
Net present value (million-\$): & & \\
Revenue requirements & 10,000 & \\
Environmental costs & 3,150 & \\
Average electricity price (c/kWh) & 6.89 & \\
Average electric bill (\$/customer) & 1,190 & \\
\hline
\end{tabular}

Source: Appendix Table A1. 
Electricity consumption increases at an average rate of $2.0 \% / y e a r$ in this case, driven partly by the growth in the number of new customers ( $0.8 \% / y e a r)$. Real electricity prices increase slowly at $0.6 \%$ year. Utility assets increase slightly faster than growth in electricity use, at $0.9 \%$ year. Construction expenditures peak at $\$ 170$ million in 1996 and again at $\$ 160$ million in 2003 (Fig. 6). Over the 20-year period, the utility spends $\$ 1,880$ million on new construction, of which $67 \%$ is for new power plants. The remainder is for transmission and distribution and other investments.

The NPV of revenue requirements, $\$ 10.0$ billion, is computed with the utility's weighted average cost of capital (about 10.5\%) to bring all the costs back to 1990 .

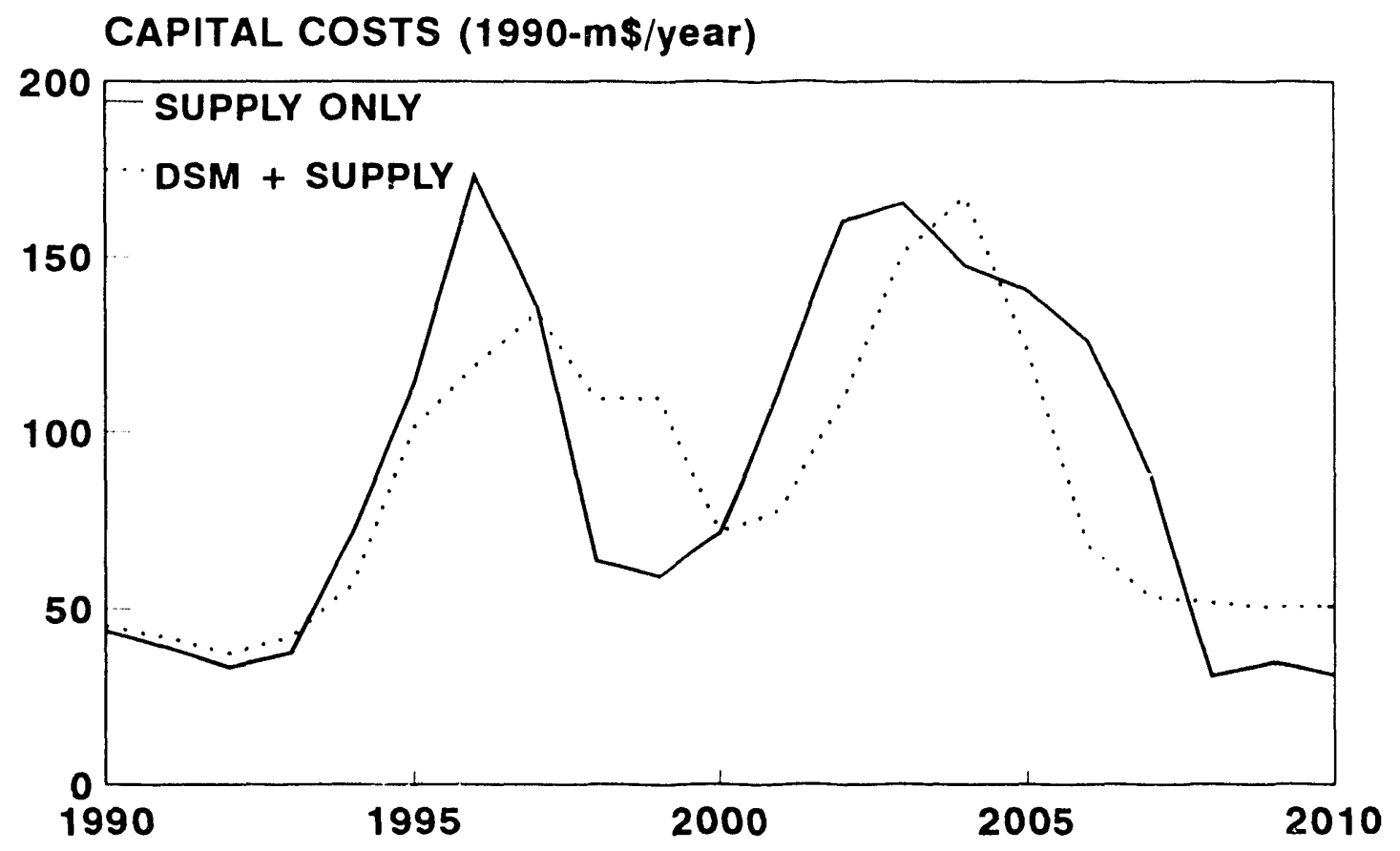

Fig. 6. Capital costs (for power plants, DSM programs, and transmission and distribution facilities) for the supply-only base case and the $4.5 \mathrm{c} / \mathrm{kWh}$ DSMprogram case discussed in the next section.

\section{DSM CASES}

Starting with the supply plan discussed above, several cases were developed that incorporated DSM programs of different intensities. Intensity refers to the utility's incentive payment for energy-efficiency investments (expressed as the maximum CCE) and its marketing budget per participant. In all cases, DSM programs were started in 1990 for both existing and new customers and were run unchanged for the full 20 years of the simulation. In addition, the utility always paid $100 \%$ of the costs associated with DSM measures. 
Programs were tested with maximum costs of $6,5,4.5,4$, and $3 \mathrm{c} / \mathrm{kWh}$. No effort was made to optimize the DSM programs by testing different combinations of marketing budgets and financial incentives for DSM measures. For example, requiring participants to pay part of the cost of DSM measures would lower utility costs, reducing the adverse effect on electricity prices (the RIM test). However, this strategy would also reduce the amount of energy savings obtained from the DSM programs.

In all these DSM cases, some of the power plants that were constructed in the supplyonly case are deferred or displaced by the energy and capacity resources provided by the DSM programs. The analysis proceeded as follows. The DSM program, begun in 1990, was added to the full set of power plants constructed in the supply-only case. Then, several additional cases were run in which some of these power plants were deferred or eliminated. These iterations stopped when revenue requirements could be reduced no further, subject to the constraint that the reserve margin was roughly what it was in the supply-only case. Thus, each DSM case has just enough supply projects to maintain the same average reserve margin as in the supply-only case.

Results for the case with a maximum CCE of $4.5 \mathrm{c} / \mathrm{kWh}$ are shown in Table 7 and in Figs. 7 and 8 . The DSM program aimed at new construction cuts electricity use and peak demand per participant by $41 \%$; the comparable figure for the program aimed at existing construction is $27 \%$. The fraction of new customers participating increases steadily during the two-decade period (Fig. 3). The participation of existing customers increases until 2002 and then begins to decline because there are few nonparticipating customers left. The utility's capital costs for the programs aimed at new and existing customers are shown in Fig. 7.

The program aimed at existing facilities, whose costs are shown in Fig. 7, is limited to facilities in operation as of 1985 ; thus the pool of eligible customers declines steadily over time, which explains why the costs for this program decrease after 2002. The program aimed at new construction has as its eligible pool customers that are new to the system in a particular year. If customers do not participate that year, they cannot participate later in either the new or the existing program.

Over the 20-year period, construction costs total $\$ 1,770$ million, $6 \%$ less than in the supply-only case (Fig. 6). Also, construction of new power plants accounts for a smaller share of the total in the DSM case (35\%) than in the base case (67\%). Whereas $1400 \mathrm{MW}$ of new power plants were constructed in the supply-only case, only $800 \mathrm{MW}$ of new power plants were constructed in the DSM case. Thus, these DSM programs displace the need for almost half the power plants that would otherwise have been built.

Electricity use in this case grows more slowly than in the supply-only case (1.2 vs $2.0 \%$ year) and in the year 2010 is $15 \%$ lower (Fig. 8). Correspondingly, utility revenues, assets, and customer bills are lower with the DSM programs. According to the TRC test, these DSM programs have a benefit/cost ratio of 2.7. The average CCE for these DSM programs (including the cost of the measures plus the utility's cost of program administration 
and marketing) is about $3.5 \mathrm{c} / \mathrm{kWh}$ at the customer meter, roughly two-thirds the cost of a small coal plant. Accounting for transmission and distribution losses (5\% for energy and $10 \%$ for peak) plus transmission and distribution construction makes the DSM programs even more cost effective.

Tabie 7. Summary of results for a combined supply/demand plan with DSM resources purchased up to $4.5 \mathrm{c} / \mathrm{kWh}$ for the base utility

\begin{tabular}{lcc}
\hline & \multicolumn{2}{c}{$\begin{array}{c}\text { Average growth rate, 1990-2010 } \\
\text { (\%/year) }\end{array}$} \\
\cline { 2 - 3 } & DSM & Supply-only \\
Total electricity use (GWh/year) & 1.2 & 2.0 \\
Electricity price (c/kWh) & 0.9 & 0.6 \\
Average electric bill (\$/customer) & 1.3 & 1.9 \\
Utility revenues (million-\$) & 2.1 & 2.7 \\
Utility assets (million-\$) & 0.04 & 0.9 \\
& & Percentage change \\
Summary statistics, 1990-2010 & & relative to base (Table 6) \\
Net present value (million-\$): & & -5.5 \\
$\quad$ Revenue requirements & & -2.2 \\
Environmental costs & 9,450 & +0.7 \\
Average electricity price (c/kWh) & 3,080 & -7.6 \\
Average electric bill (\$/customer) & 6.94 & 1,100 \\
\hline
\end{tabular}

Source: Tables A1 and A2.

Electricity prices are slightly higher with DSM programs. As shown in Fig. 8, electricity prices are initially almost unchanged because of the DSM programs and then ıncrease from 2005 to 2010. At the end of the analysis period, electricity prices are higher with DSM programs than without because no new power plants are started at the end of the period. In the supply-only case, construction costs for new power plants are zero in 2009 and 2010. However, in the DSM case, the DSM programs continue unchanged through the year 2010, leading to higher construction costs from 2008 to 2010 (Fig. 6).

Overall, electricity prices are $0.7 \%$ higher, but electric bills are $8 \%$ lower, and utility revenue requirements are almost $6 \%$ lower. Bills and utility revenues are consistently lower throughout the 20-year period with DSM programs (Fig. 8). 
DSM CAPITAL COSTS (1990-m\$/year)

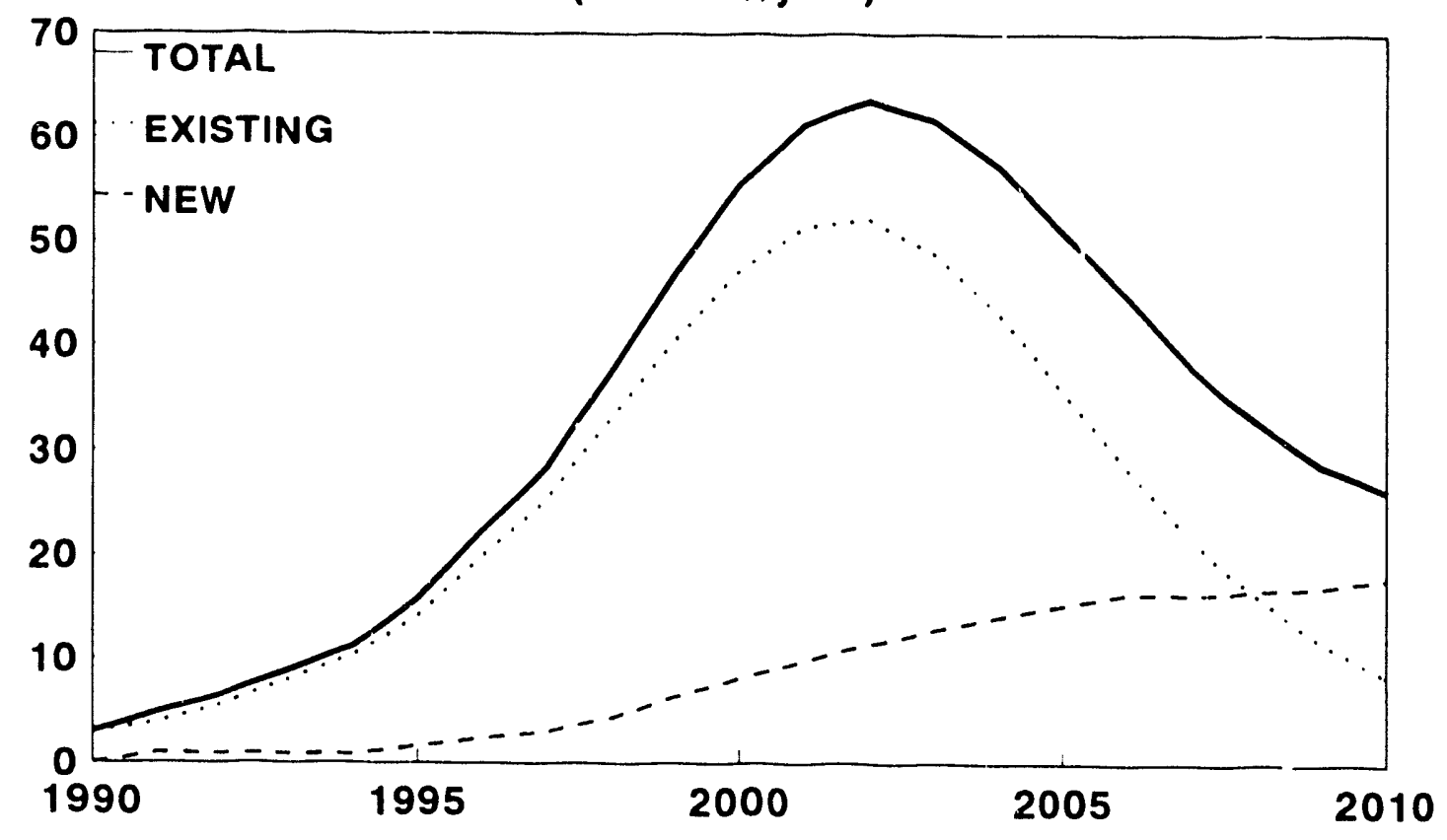

Fig. 7. Utility costs for DSM programs aimed at new and existing customers with a maximum CCE of $4.5 \mathrm{c} / \mathrm{kWh}$. Expenditures on the program for existing customers peak in 2002 because that is when participation peaks (Fig. 3).

\section{PERCENTAGE CHANGE FROM BASE}

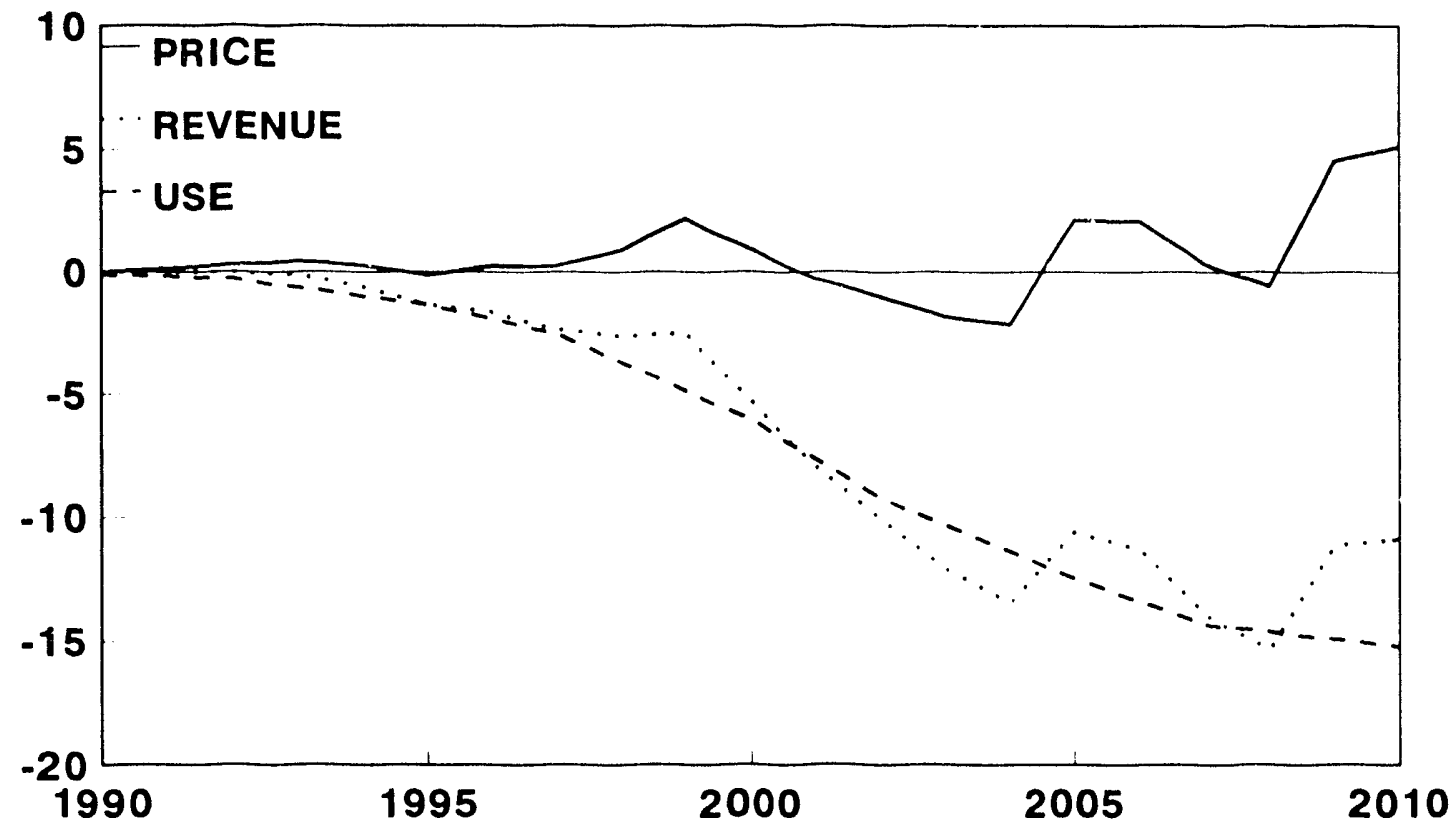

Fig. 8. Effects of a utility DSM program $(\mathrm{CCE}=4.5 \mathrm{c} / \mathrm{kWh})$ on electricity use, revenues (and average electric bill), and electricity price. Model results for the last few years of the simulation are confounded by the fact that no new power plants are under construction to meet post-2010 electricity needs. 
Although the net present value (NPV) of utility revenues is lower by $5.5 \%$ with DSM programs, the reduction in the NPV of environmental costs is only $2.2 \%$. This difference occurs because the existing (pre-1990) power plants are much more polluting than are new ones; DSM programs defer construction of new plants but have only modest effects on the operation of existing plants. An analysis of the electric-power system in New England came to a similar conclusion (Connors and Andrews 1991).

Other cases with different DSM programs were run, and the comparisons between each of these cases and the supply-only case are shown in Fig. 9. At values of maximum $\mathrm{CCE}$ above $5 \mathrm{c} / \mathrm{kWh}$, conservation programs increase both electricity bills and prices relative to cases with moderate conservation programs. These results also show that it is possible to reduce both revenue requirements and electricity prices with modest DSM programs. For example, the case with maximum $\mathrm{CCE}$ of $3 \mathrm{c} / \mathrm{kWh}$ yields an average reduction in electricity price of $0.7 \%$ relative to the supply-only case. Even this "modest" program cuts electricity use in the year 2010 by $11 \%$ and cuts reventie requirements by $4.7 \%$ (compared with the $15 \%$ cut in 2010 electricity use and the $5.6 \%$ cut in revenue requirements achieved with the $4.5 \mathrm{c} / \mathrm{kWh}$ program).

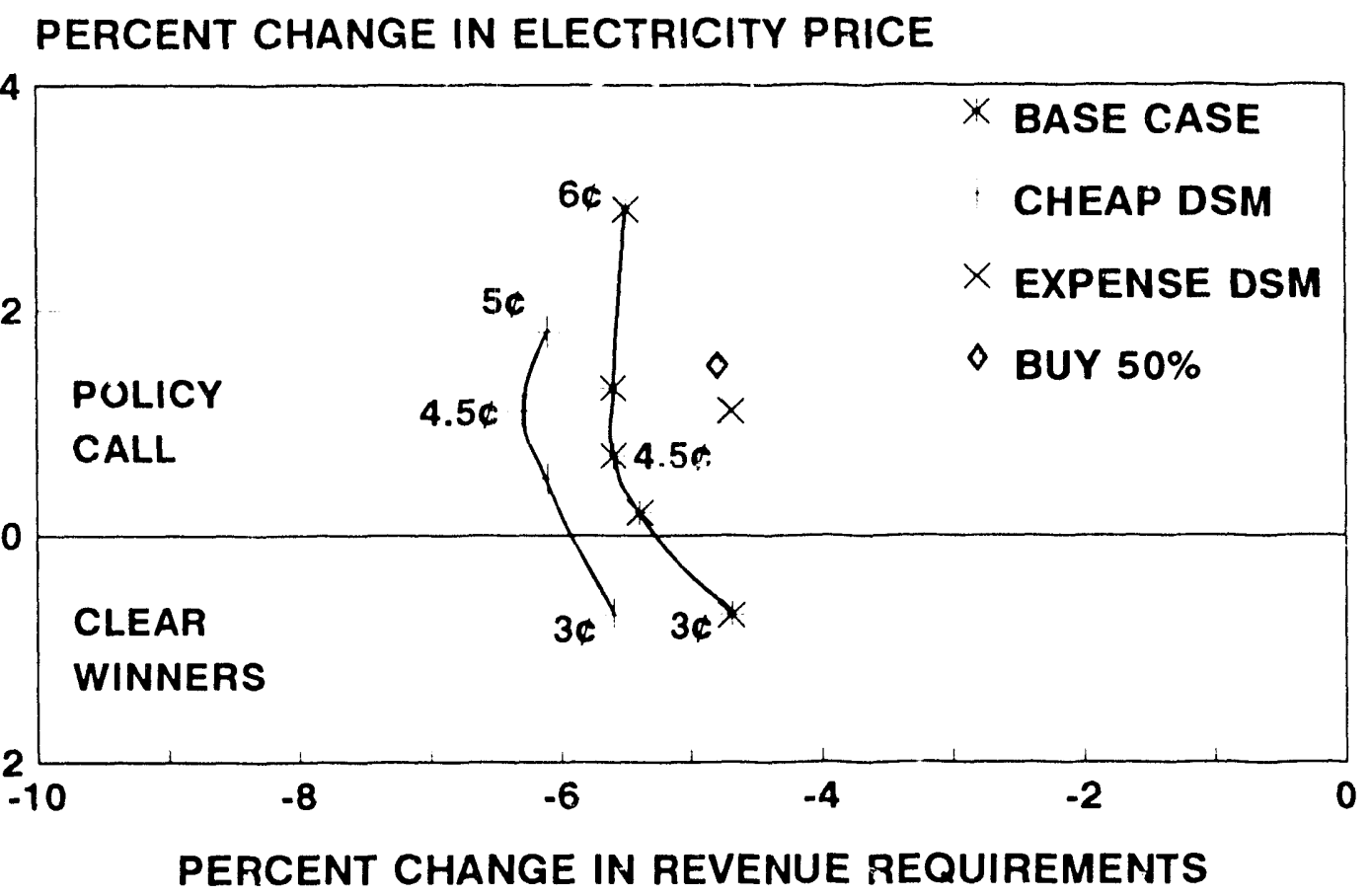

Fig. 9. The effects of utility DSM programs on NPV of utility revenues and average electricity price (1990 through 2010) for the base utility. The prices shown refer to the maximum CCE (in $c / k W h$ ) paid by the utility in its DSM programs. The $X$ refers to the case when the costs of the DSM programs are expensed rather than capitalized over 15 years. The diamond refers to the case when the utility gets half its additional supplies from long-term purchases and half from consiruction of its own power plants. 


\section{EXPENSING VS RATE-BASING DSM}

In the cases discussed above, the utility's costs of its DSM programs were capitalized and depreciated over 15 years. This financial treatment of DSM is consistent with the treatment of other investments (e.g., in power plants and transmission and distribution systems) and ensures that the costs and benefits of DSM are roughly contemporaneous.

However, utilities often treat DSM-program costs as an expense, which means that they recover these costs the year they occur; these costs appear immediately in electricity prices. I tested the effects of different financial treatments of DSM programs on the tradeoff between total costs and electricity prices: expensing, rate-basing with a 10-year depreciation, and rate-basing with a 15-year depreciation (Table 8 and Fig. 9).

These results show that expensing DSM-program costs, rather than rate-basing these costs, reduces the benefits of these programs. This finding is true for both the TRC and the RIM tests, affecting both utility costs and electricity prices. Expensing increases utility costs relative to the supply-only case each year from 1990 through 1997; it is only in the later years that revenues are lower with expensing. Contrast this situation with the one when DSM-program costs are rate-based (shown in Fig. 8); there, revenue requirements are lower every year with DSM programs than without.

This difference in the timing of DSM-program costs shows up in electricity prices also (Fig. 10). Prices are higher with DSM programs than without until 20()3 if DSM-program costs are expensed. As discussed above, if these costs are depreciated over 15 years, DSM programs have little effect on electricity prices until the early $200(0)$, after which prices are usually higher with DSM programs than without.

As expected, the effects of depreciating DSM-program costs over ten years fall between the effects of expensing and depreciating over 15 years.

Table 8. Summary of results for cases with DSM resources purchased up to $4.5 \mathrm{c} / \mathrm{kWh}$ for the base utility and different financial treatment of DSM expenses

Summary statistics, 1990-2010
Percentage change relative to the supply-only case:

Expense

15-year depreciation depreciation

Net present value (million-\$):

Revenue requirements

Environmental costs

Average electricity price ( $\$ / \mathrm{kWh}$ )

Average electric bill (\$/customer)

$-4.7$

$-2.4$

1.1

$-5.9$
$-5.3$

$-2.3$

1.1

$-6.6$
$-5.6$

$-2.2$

0.7

$-7.1$ 


\section{ELECTRICITY PRICE (\% CHAR:}

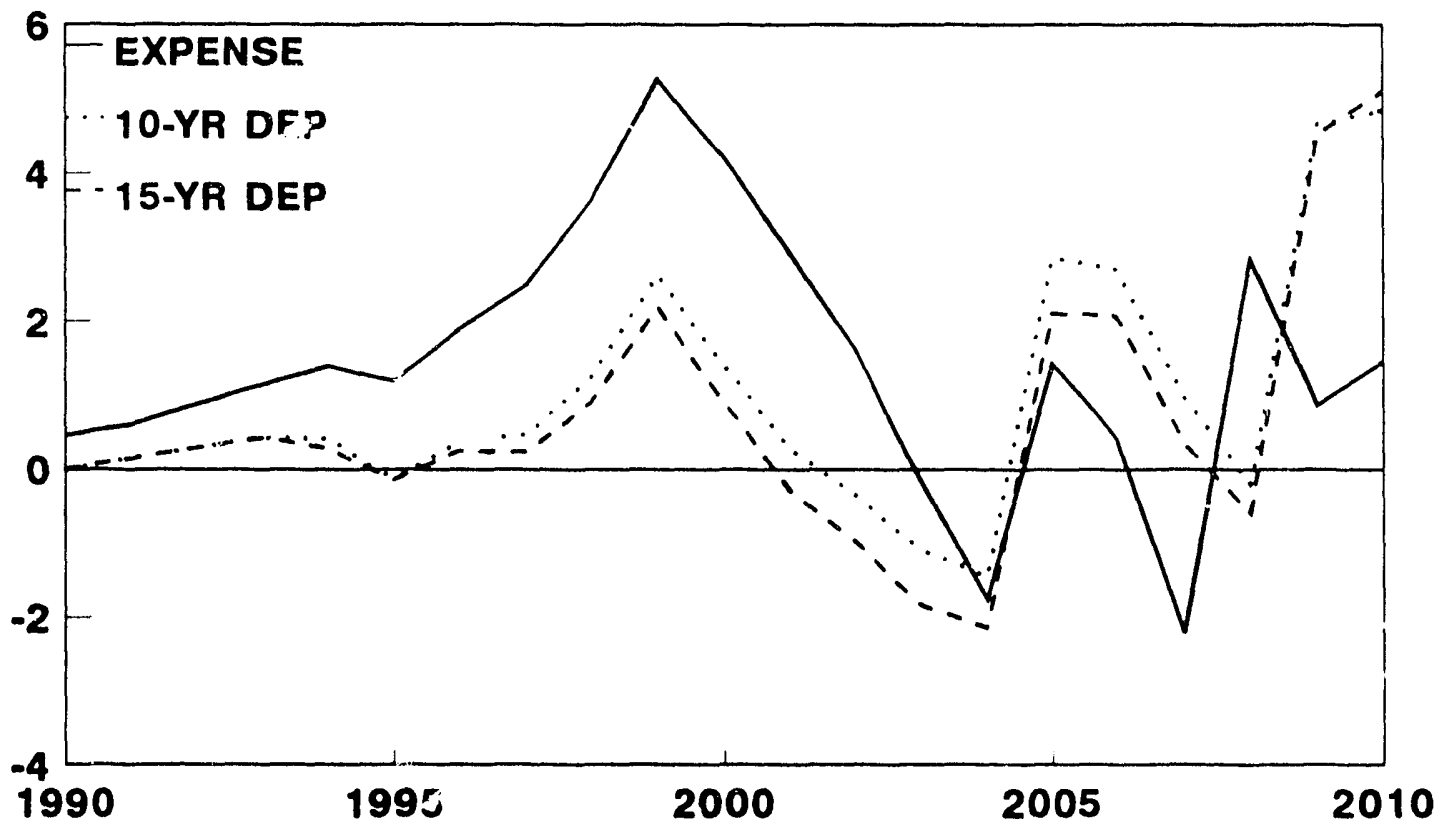

Fig. 10. The effects of different financial treatments of DSM-program costs on electricity price. The three treatments shown here are expensing, depreciation over ten years, and depreciation over 15 years.

\section{PURCHASE POWER VS CONSTRUCT POWER PLANTS}

The utility built its ov n power plants in all the cases considered so far. However, utilities frequently sign long-term contracts for additional supplies. The costs of these contracts are expensed rather than capitalized (as are power-plant construction costs). How do contrncts affect the economic attractiveness of DSM programs?

I analyzed two additional cases. In a new supply-only case, the utility substituted long-term contracts for half of the power plants it would otherwise have built. Thus, this case involves utility construction of $400 \mathrm{MW}$ of coal plants, $300 \mathrm{MW}$ of combustion turbines, and negotiation of 20-year contracts for $400 \mathrm{MW}$ of long-term baseload supply and $300 \mathrm{MW}$ of long-term peaking capacity. Similarly, in the DSM case, half the new supply is provided by utility-built power plänts and half by long-term contracts.

Compared with the cases in which the utility builds all its piants (discussed above), the benefits of DSM programs are reduced (Table 9 and Fig. 9). The reduction in revenue requirements goes from 5.6 to $4.8 \%$, and the increase in electricity price goes from 0.7 to $1.5 \%$. The reduction in benefits of DSM programs is caused by end effects. When a utility builds a power plant with a lifetime that extends beyond the end of the analysis period (2010 
in this case), the plant costs are included in the analysis, but much of the benefit is not. The same, however, is true for DSM programs. Although much of the cost for these programs is recovered before 2010 , their benefits extend beyond that date.

Table 9. Summary of results for cases with DSM resources purchased up to $4.5 \% / \mathrm{kWh}$ for she base utility with different ways to acquire new supply resources

Summary statistics,

Percentage change relative

1990-2010 to the supply-only case:

Buy $50 \%$

Build $100 \%$

Net present value (million-\$):

Revenue requirements $-4.8$ $-5.6$

Environmental costs

Average electricity price $(c / \mathrm{kWh})$

Average electric bill (\$/customer)

$-6.4$

$-7.1$

\section{VERY CHEAP DSM}

The energy-efficiency programs discussed above were cost effective from the perspective of the TRC test. However, the programs were not "too cheap to meter," as is clear from Fig. 9.

Here I examine cases similar to those developed above, except that the cost of saving energy is much lower [along the lines suggested by Lovins (1988)]. The supply-only case is the same as the one discussed above (Table 6). However, the cases with DSM programs differ from those $d_{1}$ : sssed above. In particular, the per participant savings at a given CCE are about $10 \%$ higher in these cases.

Results show that for a given maximum CCE, the reductions in electricity use and in revenu: riaguirements are much greater if conservation resources are very cheap. However, the increase in average electricity price is also greater with very cheap DSM resources, primarily because of the greater impact on electricity use, revenues, and therefore lost revenues (Fig. 9). On the other hand, for a given reduction in utility costs, the rate impact is less with cheap DSM. For example, the case with a maximum cost of conserved energy of $3 \mathrm{c} / \mathrm{kWh}$ lowers revenue requirements by $6 \%$ and lowers the average price of electricity by almost $1 \%$ (Table 10). If the maximum CCE is below about $3.5 \% / \mathrm{kWh}$, then the DSM programs reduce both revenues and prices (Fig. 9). 
Table 10. Summary of results for cases with very inexpensive DSM resources for the base utility

Summary statistics, 1990-2010
Percentage change relative to the supply-only case at different CCE:

$5 € \quad 4.5 \% \quad 4 \zeta \quad 3 €$

Net present value (million-\$):

Revenue requirements

Environmental costs

Average electricity price $(\boldsymbol{c} / \mathrm{kWh})$

Average electric bill (\$/customer)
$-6.2$

$-2.5$

1.8

$-8.2$
$-6.3$

$-2.4$

1.1

$-8.2$
$-6.2$

$-2.4$

0.5

$-7.9$
$-5.7$

$-1.4$

$-0.7$

$-7.4$ 


\section{SURPLUS UTILITY}

Here I present cases similar to those developed in Chapter 3 but with different assumptions concerning installed capacity in 1990, 1990 reserve margin, load growth, and fossil-fuel prices (Table 3). These assumptions simulate the situation in which a utility has substantial excess capacity (a $27 \%$ reserve margin in this case) and slow load growth, leading to only a modest need for additional capacity between 1990 and 2010 (only $400 \mathrm{MW}$ here, compared with $1400 \mathrm{MW}$ in the case discussed in Chapter 3). The purpose of these cases is to show whether DSM programs offer benefits to a utility with excess capacity.

As in Chapter 3, I begin with the development of a supply-only plan that minimizes the NPV of revenue requirements from 1990 to 2010 . Then, alternative plans are developed with different amounts of DSM resources. Remaining resource needs in each of these cases are provided by new power plants.

The supply-only case includes the addition of $200 \mathrm{MW}$ of coal plants and $200 \mathrm{MW}$ of combustion turbines. The resulting load growth, electricity prices, and so on are shown in Table 11.

Again, several cases with DSM programs were simulated. As before, these DSM cases differed in the maximum CCE offered by the utility. The case with a CCE of $4.5 \mathrm{c} / \mathrm{kWh}$ (the one with the greatest reduction in NPV of revenue requirements for the base utility discussed in Chapter 3 ) increased electricity price almost $4 \%$ and decreased revenue requirements $3 \%$ (compared with an increase in electricity price of $0.7 \%$ and a decrease in revenue requirements of almost $6 \%$ for the base utility; see Fig. 11). Thus, for the surplus utility, the benefits of DSM programs are much less than for the base utility from a TRC perspective and even worse from a RIM perspective.

At first glance, these reductions in revenue requirements seem startling: How can DSM programs reduce costs for a utility that has substantial excess capacity and needs no additional capacity until 2004? Because the DSM-program costs are depreciated over 15 years, revenue requirements with the DSM program are lower in all years except 1990 and 1991. In other words, the cost of the DSM programs is less than the reduction in operating costs plus the reduction in transmission and distribution construction costs. If the DSMprogram costs were expensed instead of rate-based, the revenue requirements with DSM would be greater each year from 1990 through 2002 than in the supply-only case. Again, these results show the substantial effect of financial treatment on DSM-program economics. 


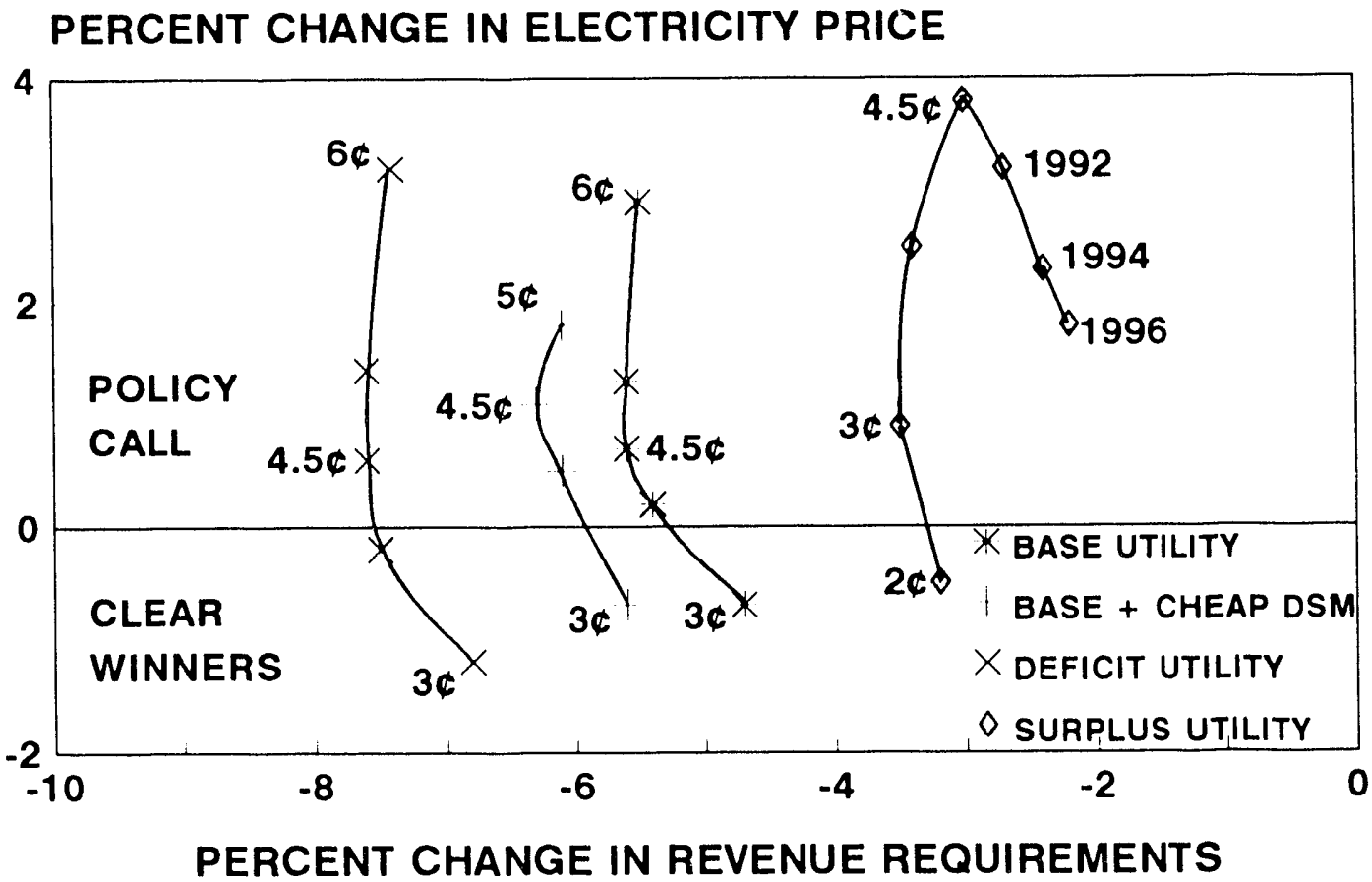

Fig. i1. The effects of utility DSM programs on NPV of utility revenues and average electricity price (1990 through 2010) for the base, surplus, and deficit utilities. The DSM programs all begin in 1990, except for the three noted with the starting years for the surplus utility. The prices shown refer to the maximum CCE (in $\$ / \mathrm{kWh}$ ) paid by the utility in its DSM programs.

The case with a CCE of $3 \mathrm{c} / \mathrm{kWh}$ led to the greatest reduction in the NPV of revenue requirements (Table 12). The DSM programs displaced the need for $75 \%$ of the power plants that were constructed in the supply-only case (i.e, 200 MW of coal plants and 100 MW of combustion turbines). With such reductions, the NPV of revenue requirements is cut by $3.5 \%$, and electricity price is higher by $0.9 \%$ (compared with $3.0 \%$ and $3.8 \%$, respectively, for the $4.5 \mathrm{c} / \mathrm{kWh}$ DSM-program case).

I also tested the effects of delaying the DSM program by two, four, or six years (Fig. 11). These delays cut both the reductions in utility revenue requirements and the increases in electricity prices. 
Table 11. Summary of results for supply-only plan for the surplus utility

\begin{tabular}{lcc}
\hline & 1990 & $\begin{array}{c}\text { Average growth } \\
\text { rate, 1990-2010 } \\
\text { (\%/year) }\end{array}$ \\
\hline Number of customers (thousands) & 694 & 0.3 \\
Total electricity use (GWh/year) & 10.3 & 1.5 \\
Electricity price (c/kWh) & 6.11 & -0.8 \\
Average electric bill (\$/customer) & 900 & 0.4 \\
Utility revenues (million-\$) & 630 & -2.2 \\
Utility assets (million-\$) & 1140 & \\
Summary statistics, 1990-2010 & & \\
Net present value (million-\$): & & \\
Revenue requirements & 7,500 & \\
Environmental costs & 3,300 & \\
Average electricity price (\$/kWh) & 5.49 & \\
Average electric bill (\$/customer) & 930 & \\
\hline
\end{tabular}

Source: Table A3.

Table 12. Summary of results for a combined supply/demand plan with DSM resources purchased up to $3 \% / \mathrm{kWh}$ for the surplus utility

\begin{tabular}{lcc} 
& \multicolumn{2}{c}{$\begin{array}{c}\text { Average growth rate, } \\
\text { (\%/year) }\end{array}$} \\
\cline { 2 - 3 } & DSM & Supply-only \\
Total electricity use (GWh/year) & 0.9 & 1.5 \\
Electricity price (\&/kWh) & -0.7 & -0.8 \\
Average electric bill (\$/customer) & -0.2 & 0.4 \\
Utility revenues (million-\$) & 0.1 & 0.7 \\
Utility assets (million-\$) & -3.3 & -2.2 \\
& & Percentage change \\
& & relative to base (Table 11) \\
Summary statistics, 1990-2010 & & -3.5 \\
Net present value (million-\$): & 7,210 & -2.0 \\
Revenue requirements & 3,250 & 0.9 \\
Environmental costs & 5.54 & -4.7 \\
Average electricity price (c/kWh) & 890 & \\
Average electric bill (\$/customer) & & \\
\hline
\end{tabular}

Source: Tables A3 and A4. 


\section{DEFICIT UTILITY}

In this chapter, I discuss cases for a utility that faces rapid load growth, has a small reserve margin in 1990, plans to retire much of its existing generating units by 2010 , and faces higher fossil-fuel prices (Table 3). In essence, these cases are the opposite of those discussed in Chapter 4.

The supply-only plan for this deficit utility involves construction of $1600 \mathrm{MW}$ of coal plants plus $300 \mathrm{MW}$ of combustion turbines. The resulting load growth, electricity prices, revenues, and assets are shown in Table 13.

As for the base and surplus utilities, I tested several cases w th DSM programs of different intensities. As showr. in Fig. 11, the reductions in revenue requirements caused by DSM programs are much greater for the deficit utility than for either the base or surplus utility. However, even for the deficit utility, most of the DSM programs increase average electricity prices. Only when the maximum CCE is at or below $4 \mathrm{c} / \mathrm{kWh}$ do both revenues and prices decline compared to the supply-only case.

The case with a CCE of $4.5 \mathrm{c} / \mathrm{kWh}$, which led to the largest reduction in revenue requirements (almost $8 \%$ ), increased the average electricity price by $0.6 \%$ (Table 14 ). This set of DSM programs cut load growth from 2.4 to $1.5 \%$ /year and displaced the construction of $500 \mathrm{MW}$ of power plants.

The cases with a maximum CCE of 4 to $6 \mathrm{c} / \mathrm{kWh}$ led to almost the same reduction in revenue requirements. However, the effects of these programs on electricity prices and consumption are large. While the $6 \% / \mathrm{kWh}$ case reduced electricity use in the year 2005 by $17 \%$, it increased the average price of electricity by more than $3 \%$. On the other hand, the $4 \mathrm{c} / \mathrm{kWh}$ case reduced electricity use by $11 \%$ and led to a $0.2 \%$ decrease in electricity price. These results show that the decision on DSM-program intensity involves more than a tradeoff between costs and prices; it also involves electricity consumption and the displacement of supply sources. 
Table 13. Summary of results for supply-only plan for the deficit utility

\begin{tabular}{lrc}
\hline & 1990 & $\begin{array}{c}\text { Average growth } \\
\text { rate, 1990-2010 } \\
\text { (\%/year) }\end{array}$ \\
\hline Number of customers (thousand) & & 1.0 \\
Total electricity use (GWh/year) & 110 & 2.4 \\
Electricity price (c/kWh) & 6.90 & 0.9 \\
Average electric bill (\$/customer) & 1,010 & 2.3 \\
Utility revenues (million-\$) & 720 & 3.3 \\
Utility assets (million-\$) & 1,300 & 2.8 \\
Summary statistics, 1990-2010 & & \\
Net present value (million-\$): & & \\
Revenue requirements & 11,530 & \\
Environmental costs & 3,290 & \\
Average electricity price (c/kWh) & 7.68 & \\
Average electric bill (\$/customer) & 1,330 & \\
\hline
\end{tabular}

Source: Table A5.

Table 14. Summary of results for a combined supply/demand plan with DSM resources purchased up to $4.5 \% / \mathrm{kWh}$ for the deficit utility

\begin{tabular}{lcc}
\hline & \multicolumn{2}{c}{$\begin{array}{c}\text { Average growth rate, } \\
\text { (\%/year) }\end{array}$} \\
\cline { 2 - 3 } & DSM & Supply-only \\
Total electricity use (GWh/year) & 1.5 & 2.4 \\
Electricity price (c/kWh) & 1.2 & 0.9 \\
Average electric bill (\$/customer) & 1.6 & 2.3 \\
Utility revenues (million-\$) & 2.6 & 3.3 \\
Utility assets (million-\$) & 1.7 & 2.8 \\
& & Percentage change \\
& & relative to base (Table 13) \\
Summary statistics, 1990-2010 & & -7.6 \\
Net present value (million-\$): & 10,660 & -2.4 \\
Revenue requirements & 3,210 & 0.6 \\
Environmental costs & 7.72 & -8.6 \\
Average electricity price (c/kWh) & 1,210 & \\
Average electric bill (\$/customer) & & \\
\hline
\end{tabular}

Source: Tables A5 and A6. 


\section{SYNTHESIS OF RESULTS}

Is the increasing use of demand-side management programs good for the customers of electric utilities? The answer, of course, depends on the criteria used to judge "goodness." Those who argue over the appropriate economic test(s) to use in selecting DSM programs see customer benefits in different ways. Some focus on the price of electricity, while others focus on the cost of electric-energy services (where services refer to the benefits provided by the combination of electricity and electricity-using devices, such as cold food in a refrigerator, an elevator that takes you to the tenth floor of an office building, and motors that operate a factory assembly line).

This report does not suggest how best to define benefits. Rather, it focuses on the tradeoffs between price and cost and identifies how much of a price increase might be associated with how much of a cost reduction when a utility provides DSM programs for its customers.

This tradeoff was explored with a new planning model developed at ORNL (DIAMOND). The model was used to examine the effects of DSM programs on revenue requirements, electricity prices, electricity consumption, environmental costs, and the need for additional power supplies under a variety of circumstances. These simulations include a base utility that corresponds roughly to the EIA projections of electricity demand, prices, construction, and so on for the United States as whole during the next two decades. In addition, the effects of DSM programs on a surplus utility (one with substantial excess capacity and low avoided costs) and a deficit utility (one that requires substantial new resources and faces high avoided costs) were simulated (Table 15). In all these cases, the utility was assumed to pay $100 \%$ of the cost of purchasing and installing the DSM measures; that is, customers paid nothing for these improvements. These cases, therefore, represent the extreme in terms of both the TRC and RIM tests.

The base-case results (Chapter 3 ) show that the percentage reductions in customer costs (reflected by utility revenue requirements) are much greater than the percentage increases in electricity prices. This finding holds regardless of whether the utility costs of running DSM programs are expensed or capitalized and regardless of whether the utility

"Cicchetti and Hogan (1989) suggested a way to overcome these increases in electricity prices. Their proposal called for the utility to install all measures costing less than the utility's long-term avoided cost (conforming to the TRC test). Participating customers would then repay the utility through monthly bills for the difference between the utility's avoided cost and retail electricity price (conforming to the RIM test). 
Table 15. Summary of results for all the simulations presented here

\begin{tabular}{|c|c|c|c|c|c|c|c|}
\hline & \multicolumn{7}{|c|}{ Percentage change from supply-only case } \\
\hline & \multicolumn{3}{|c|}{ NPV-RR ${ }^{\mathrm{a}}$} & \multicolumn{2}{|c|}{ Average } & \multirow{2}{*}{$\begin{array}{l}2005 \\
\text { price }\end{array}$} & \multirow{2}{*}{$\begin{array}{l}2005 \\
\text { demand }\end{array}$} \\
\hline & $\begin{array}{l}199()- \\
2010\end{array}$ & $\begin{array}{l}1990-1 \\
2030\end{array}$ & $\begin{array}{l}\text { Environment } \\
199()-2010\end{array}$ & Price & Bill & & \\
\hline \multicolumn{8}{|l|}{ Chapter 3 : base utility } \\
\hline DSM $(a) 6 / \mathrm{kWh}$ & -5.5 & -7.2 & -2.4 & 2.9 & -7.3 & 5.1 & -15.2 \\
\hline $\mathrm{DSM}(\alpha) 5 \mathrm{c} / \mathrm{kWh}$ & -5.6 & -7.3 & -2.4 & 1.3 & -7.3 & 3.3 & -13.1 \\
\hline DSM $(a) 4.5$ c/kWh & -5.6 & -7.2 & -2.2 & 0.7 & -7.1 & 2.1 & -12.4 \\
\hline DSM @ 4 c/kWh & -5.4 & -6.9 & -2.1 & 0.2 & -6.8 & -7.4 & -11.0 \\
\hline DSM @ 3 c/kWh & -4.7 & -6.4 & -1.2 & -0.7 & -6.2 & -6.4 & -9.0 \\
\hline \multicolumn{8}{|l|}{ DSM (a $4.5 c / \mathrm{kWh}$} \\
\hline Expense & -4.7 & -7.3 & -2.4 & 1.1 & -5.9 & 1.5 & -10.3 \\
\hline 10-year depreciation & -5.3 & -7.0 & -2.3 & 1.1 & -6.6 & 2.8 & -11.7 \\
\hline Buy $50 \%$ and build $50 \%$ & -4.8 & -6.1 & -2.3 & 1.5 & -6.4 & 2.2 & -12.3 \\
\hline Cheap DSM@ 5 c/kWh & -6.2 & -8.2 & -2.5 & 1.8 & -8.2 & 3.8 & -15.2 \\
\hline Cheap DSM @ 4.5 c/kWh & -6.3 & -8.3 & -2.4 & 1.1 & -8.2 & 2.5 & -14.5 \\
\hline Cheap DSM@ @ c/kWh & -6.2 & -8.2 & -2.4 & 0.5 & -7.9 & 1.8 & -13.1 \\
\hline Cheap DSM @ 3 c/kWh & -5.7 & -8.0 & -1.4 & -0.7 & -7.4 & -1.0 & -11.0 \\
\hline \multicolumn{8}{|l|}{ Chapter 4: surplus utility } \\
\hline DSM @ 5 c/kWh & -2.6 & -4.6 & -3.2 & 5.0 & -4.3 & 7.8 & -16.5 \\
\hline DSM (a) 4.5 c/kWh & -3.0 & -5.2 & -2.8 & 3.8 & -4.7 & 5.3 & -15.0 \\
\hline DSM@ 4 c/kWh & -3.4 & -5.7 & -2.5 & 2.5 & -4.9 & 2.7 & -13.5 \\
\hline DSM@ $3 c / k W h$ & -3.5 & -5.8 & -2.0 & 0.9 & -4.7 & 0.0 & -10.5 \\
\hline DSM@ 2 c/kWh & -3.2 & -5.1 & -1.5 & -0.5 & -4.0 & -2.7 & -6.8 \\
\hline DSM@ 4.5 c/kWh, 1992 & -2.7 & -4.7 & -2.1 & 3.2 & -4.3 & 4.6 & -13.5 \\
\hline DSM@ @ 4.5 c/kWh, 1994 & -2.4 & -4.1 & -1.5 & 2.3 & -3.7 & 2.5 & -11.3 \\
\hline DSM@4.5 c/kWh, 1996 & -2.2 & -3.7 & -1.0 & 1.8 & -3.3 & 2.1 & -9.8 \\
\hline \multicolumn{8}{|l|}{ Chapter 5: deficit utility } \\
\hline DSM@6 c/kWh & -7.4 & -8.7 & -2.7 & 3.2 & -8.4 & 2.9 & -17.1 \\
\hline DSM@ 5 c/kWh & -7.6 & -9.0 & -2.5 & 1.4 & -8.7 & 2.0 & -15.1 \\
\hline DSM@ $4.5 \mathrm{c} / \mathrm{kWh}$ & -7.6 & -9.0 & -2.4 & 0.6 & -8.6 & 0.9 & -13.8 \\
\hline DSM $@ 4$ c/kWh & -7.5 & -8.8 & -2.3 & -0.2 & -8.4 & -0.1 & -10.5 \\
\hline DSM@3c/kWh & -6.8 & -7.9 & -2.0 & -1.1 & -7.5 & -1.3 & -9.9 \\
\hline
\end{tabular}

${ }^{a}$ NPV-RR is net present value of revenue requirements. 
builds new power plants or uses long-term contracts to provide additional supplies. Thus, the appropriate question to ask in regulatory proceedings and utility boardrooms is: Is a $1 \%$ average increase in electricity price justified by a $5 \%$ decrease in electricity costs over the next 20 years?

The analyses discussed here also suggest that it is possible (although unlikely) to reduce both costs and prices. The circumstances under which this can occur include rapidly increasing fuel prices, the need for large amounts of new resources, and truly inexpensive DSM. Inexpensive DSM implies not just that the cost of the measures and their installation is cheap, but also that the cost to the utility to plan, design, implement, promote, and evaluate the program is low. For example, on an engineering-economic basis, low-flow showerheads are remarkably cost effective. However, utility programs that promote installation and use of such devices among their residential customers have administrative and marketing costs that exceed the cost of the showerhead itself (Flaim, Miedema, and Clayton 1989).

The analyses presented here understate the benefits of DSM programs in two ways (both of which are shown in Table 15). First, the environmental costs associated with electricity production, while included approximately in the calculations, are not emphasized in the figures and interpretation of results. Second, the post-2010 benefits and costs of DSM are not discussed. Accounting explicitly for environmental costs and for the long-term effects of DSM would increase the benefits to customers of DSM programs.

The primary findings from the analyses conducted here are:

- In general, DSM programs reduce electricity costs and raise electricity prices. Utilities and PUCs must make tradeoffs between the TRC and the RIM iests.

- Typically, the percentage reduction in electricity cost far exceeds the percentage increase in electricity price caused by DSM programs. Roughly speaking, the ratio of percentage changes is $2: 1$ for the surplus utility, 5:1 for the base utility, and $8: 1$ for the deficit utility.

The financial treatment of DSM programs is important. Expensing the costs of DSM programs raises electricity prices in the short term, whereas capitalizing these costs over 15 years defers the price increase for several years. Overall, expensing reduces the cost and price benefits of DSM programs.

- Even if DSM is very inexpensive or the utility faces very high avoided costs, the tradeoff (conflict) between costs and prices remains. However, under either of these circumstances, the percentage reduction in costs will be far greater than the percentage increase in prices. In special cases where the cost per $\mathrm{kWh}$ of DSM programs is very low, both prices and costs can be reduced. 
- From the perspective of the TRC test, DSM programs are cost effective even if the utility has excess capacity and slow load growth. This situation occurs because DSM programs offset not just the operating costs of existing power plants, but also reduce the other costs of operating the utility system, defer construction of new transmission and distribution facilities, and in the long term defer the construction and operation of new power plants.

- The tradeoff between the TRC and RIM tests can be reduced by having customers share in the costs of the DSM measures installed by the program, by reducing the maximum CCE paid by the utility, or by delaying implementation of the program. However, each of these approaches also reduces the amount of electricity savings achieved by the programs, increasing the need for additional power supplies.

Based on these simulations, I recommend that utilities and PUCs adopt a flexible approach to the assessment of DSM programs. Rather than adhering strictly to any single measure of cost effectiveness, the parties should modify program design and timing so that DSM programs provide major reductions in electric-energy-service costs (the TR ${ }_{-}$test) with only minor increases in electricity prices (the RIM test). In particular, I urge that the large reductions in total costs not be foregone because of small increases in electricity prices.

\section{ACKNOWLEDGMENTS}

I thank Michael Gettings and Evelin Yourstone, who did much of the work in developing the DIAMOND model. I appreciate the many helpful comments on a draft of this report from Paul Centolella, Richard Clarke, Thomas Foreman, Charles Goldman, Lawrence Hill, John Hughes, Jonathan Lowell, Richard Morgan, David Moskovitz, Larry Ruff, Ken Schafer, James Wolf, and Evelin Yourstone. I thank Fred O'Hara for editing the report and Ethel Schorn for proofreading and assembling the final report. 


\section{REFERENCES}

California Collaborative 1990, Report of the Statewide Collaborative Process, An Energy Efficiency Blueprint for California, available from the California Public Utilities Commission and Pacific Gas and Electric Company, San Francisco, CA, January.

California Public Utilities Commission and California Energy Commission 1987, Standard Practice Manual, Economic Analysis of Demand-Side Management Programs, San Francisco and Sacramento, CA, December.

R. C. Cavanagh 1986, "Least-Cost Planning Imperatives for Electric Utilities and Their Regulators," The Harvard Environmental Law Review 10(2), 299-344.

P. Centolella 1991, personal communication, Ohio Office of the Consumers' Counsel, Columbus, OH, September.

C. J. Cicchetti and W. Hogan 1989, "Iricluding Unbundled Demand-Side Options in Electric Utility Bidding Programs," Public Utilities Fortnightly 12.3(12), June 8.

S. R. Connors and C. J. Andrews 1991, "The Role of Demand-Side Management in Strategic Emissions Reduction: Integrating End-Use Efficiency Improvements in the Electric Power Sector," Demand-Side Management and the Global Environment, 293-304, Synergic Resources Corporation, Bala Cynwyd, PA, April.

Electricity Consumers Resource Council 1990, Profiles in Electricity Issues: Demand Side Management, No. 14, Washington, DC, December.

Electric Power Research Institute 1986, TAG-Technical Assessment Guide, Volume 1: Electricity Supply-1986, EPRI P-4463-SR, Palo Alto, CA, December.

Energy Information Administration 1989, Electric Power Annual 1988, DOE/EIA-0348(88), U.S. Department of Energy, Washington, DC, December.

Energy Information Administration 1991, Annual Outlook for U.S. Electric Power 1991, Projections Through 2010, DOE/EIA-(0474(91), U.S. Department of Energy, Washington, DC, July.

A. Faruqui et al. 1990, Impact of Demand-Side Management Programs on Future Customer Electricity Demand: An Update, EPRI CU-6953, Electric Power Research Institute, Palo Alto, CA, September. 
T. Flaim, A. K Miedema, and C. A. Clayton 1989, "The Impact of Financial Incentives on the Cost-Effectiveness of DSM Programs: Some Experimental Results," Demand-Side Management: Partnerships in Planning for the Next Decade, Proceedings of the ECNE National Conference on Utility DSM Programs, EPRI CU-6598, Electric Power Research Institute, Palo Alto, CA, November.

M. Gettings, E. Hirst, and E. Yourstone 1991, DIAMOND: A Model of Incremental Decision Making for Resource Acquisition by Electric Utilities, ORNL/CON-315, Oak Ridge National Laboratory, Oak Ridge, TN, February.

L. J. Hill 1991, Comparison of Methods to Integrate DSM and Supply Resources in ElectricUtility Planning, draft, ORNL/CON-341, Oak Ridge National Laboratory, Oak Ridge, TN.

E. Hirst 1989, "The Great Demand-Side Bidding Debate Rages On," The Electricity Joumal 2(2), 41-43, March.

E. Hirst 1991a, Possible Effects of Electric-Utility DSM Programs, 1990 to 2010, ORNL/CON312, Oak Ridge National Laboratory, Oak Ridge, TN, January.

E. Hirst 1991b, "An Exchange of Views," The Electricity Journal 4(6), 54, July.

A. E. Kahn 1991a, "An Economically Rational Approach to Least-Cost Planning," The Electricity Journal 4(5), 11-20, June.

A. E. Kahn 1991b, "An Exchange of Views," The Electricity Journal 4(6), 55, July.

J. Koomey 1990, Comparative Analysis of Monetary Estimates of External Environmental Costs Associated with Combustion of Fossil Fuels, LBL-28313, Lawrence Berkeley Laboratory, Berkeley, CA, July.

F. Krause and J. Eto 1988, Least-Cost Planning Handbook for Public Utility Commissioners, Volume 2, The Demand Side: Conceptual and Methodological Issues, National Association of Regulatory Utility Commissioners, Washington, DC, December.

A. Lovins 1988, "If Customers Save Electricity, Must Rates Rise?" Rocky Mountain Institute, Snowmass, CO.

A. Lovins 1989, "The Great Demand-Side Bidding Debate Rages On," The Electricity Journal 2(2), 34-40, March.

Maine Public Utilities Commission 1987, Rule Concerning Cost Effectiveness of Utility Energy Efficiency Investments and Programs (Chapter 38), Docket No. 86-81, Augusta, ME, March.

C. Marnay and G. A. Comnes 1990, Ratemaking for Conservation: The Califormia ERAM Experience, LBL-28019, Lawrence Berkeley Laboratory, Berkeley, CA, March. 
Massachusetts Department of Public Utilities 1988, Investigation ty the Department ... into the Pricing and Ratemaking Treatment ... , D.P.U. 86-36-F, Boston, MA, iVovenber.

Michigan Department of Commerce 1987, Michigan Electricity Options Study, Working Group \#4 Report-New Utility Power Plant Options, Lansing, MI, August.

L. E. Rı: 1988, Utility Least-Cost Planning: Five Common Fallacies and One Simple Truth, Putnam, Hayes \& Bartlett, Inc., Washington, DC, January. 


\section{APPENDIX A: DIAMOND OUTPUTS FOR KEY CASES}

Table A1. Sumary report for case shown in Table 6, supply-only plan for base utility

\begin{tabular}{|c|c|c|c|c|c|c|c|c|c|}
\hline NO. CUSTOMERS (thousands) & $\begin{array}{r}1990 \\
711\end{array}$ & $\begin{array}{r}1992 \\
728\end{array}$ & $\begin{array}{r}1995 \\
744\end{array}$ & $\begin{array}{r}1997 \\
755\end{array}$ & $\begin{array}{r}2000 \\
772\end{array}$ & $\begin{array}{r}2002 \\
783\end{array}$ & $\begin{array}{r}2005 \\
801\end{array}$ & $\begin{array}{r}2007 \\
812\end{array}$ & $\begin{array}{r}2010 \\
831\end{array}$ \\
\hline \multicolumn{10}{|l|}{ AGGREGATE USE } \\
\hline $\begin{array}{l}\text { TOTAL (thousand GWh/Yr) } \\
\text { DSM EFFECT }\end{array}$ & \multicolumn{8}{|c|}{ DSM EFFECT } & 15.64 \\
\hline thousand GWh/year & 0.001 & 0.004 & 0.009 & 0.015 & 0.029 & 0.045 & 0.079 & 0.112 & 0.176 \\
\hline & 0.2 & 0.6 & 1.5 & 2.6 & 5.1 & 7.7 & 13.7 & 19.4 & 30.4 \\
\hline LOAD FACTOR & 0.660 & 0.660 & 0.660 & 0.660 & 0.660 & 0.660 & 0.660 & 0.660 & 0.660 \\
\hline PEAK (MW) & 1818 & 1924 & 2084 & 2192 & 2325 & 2402 & 2514 & 2580 & 2704 \\
\hline \multicolumn{10}{|l|}{ INDEPENDENT VARIABLES } \\
\hline INCOME (Real) & 1.28 & 1.35 & 1.46 & 1.53 & 1.65 & 1.74 & 1.88 & 1.98 & 2.14 \\
\hline INFLATION INDEX & 1.24 & 1.33 & 1.49 & 1.61 & 1.81 & 1.95 & 2.19 & 2.36 & 2.64 \\
\hline REGIONAL SUPLUS/DEFICIT & 0.52 & 0.52 & 0.54 & 0.55 & 0.55 & 0.55 & 0.55 & 0.55 & 0.55 \\
\hline ELECTRICITY PRICE (c/kWh) & 6.46 & 6.74 & $7.5 ?$ & 8.41 & 9.98 & 11.17 & 13.27 & 14.47 & 15.67 \\
\hline RETAIL GAS PRICE (\$/MBtu) & 4.36 & 4.94 & 5.96 & 6.77 & 8.20 & 9.33 & 11.33 & 12.91 & 15.73 \\
\hline UTILITY GAS PRICE (\$/MBTU) & 3.12 & 3.60 & 4.47 & 5.16 & 6.39 & 7.38 & 9.15 & 10.55 & 13.08 \\
\hline COAL PRICE (\$/MBTU) & 1.61 & 1.80 & 2.14 & 2.40 & 2.85 & 3.20 & 3.80 & 4.26 & 5.05 \\
\hline NUCLEAR FUEL PRICE (\$/MBtu) & 0.85 & 0.93 & 1.05 & 1.14 & 1.29 & 1.40 & 1.59 & 1.73 & 1.96 \\
\hline \multirow{2}{*}{\multicolumn{10}{|c|}{$\begin{array}{l}\text { PRODUCTION RESULTS } \\
\text { ENERGY (GWh) }\end{array}$}} \\
\hline & & & & & & & & & \\
\hline REQUIRED & 11035 & 11679 & 12653 & 13308 & 14117 & 14580 & 15263 & 15664 & 16418 \\
\hline PRODUCED & 11606 & 12283 & 13247 & 13923 & 14100 & 14572 & 1529 & 15086 & 15842 \\
\hline PURCHASED LT (SOLD) & 0 & 0 & 0 & 0 & 0 & 0 & 0 & 0 & 0 \\
\hline PURCHASED ST (SOLD) & -571 & -604 & -594 & -616 & 16 & 8 & -30 & 578 & 575 \\
\hline PEAK OUTPUT (MW) & 2000 & 2116 & 2293 & 2411 & 2558 & 2642 & 2766 & 2838 & 2975 \\
\hline IW CAPABILITY (MW) & 2275 & 2275 & 2275 & 2375 & 2525 & 2625 & 282 & 2875 & 3075 \\
\hline RESERVE MARGIN & 0.14 & 0.08 & -0.01 & -0.02 & -0.01 & -0.01 & 0.02 & 0.01 & 0.03 \\
\hline \multicolumn{10}{|l|}{ SHORT-RUN MARGINAL COSTS $(c / k w h)$} \\
\hline ON-PEAK & 2.620 & 3.224 & 11.776 & 13.160 & 15.660 & 17.626 & 12.416 & 14.254 & 16.758 \\
\hline OFF-PEAK & 2.528 & 3.017 & 3.725 & 4.577 & 8.395 & 9.633 & 11.850 & 13.669 & 16.758 \\
\hline \multicolumn{10}{|l|}{ CAPITAL INVESTMENTS (M\$) } \\
\hline$T \& D$ & 39.42 & 30.48 & 36.43 & 38.11 & 37.50 & 33.15 & 41.37 & 53.20 & 59.20 \\
\hline CONSERVATION, NEW & 0.25 & 0.27 & 0.31 & 0.34 & 0.41 & 0.47 & 0.59 & 0.71 & 0.96 \\
\hline CONSERVÄTION, EXISTING & 1.27 & 1.38 & 1.60 & 1.78 & 2.14 & 2.45 & 3.0 & 3.60 & 4.43 \\
\hline OTHER & 1.05 & 0.99 & 1.25 & 1.28 & 1.15 & 0.86 & 1.16 & 1.67 & 1.82 \\
\hline GENERATION PROJECTS & 2.47 & 3.13 & 97.01 & 135.00 & 62.91 & 215.43 & 201.13 & 108.51 & 0.00 \\
\hline \multicolumn{10}{|l|}{ INCOME STATEMENT (Million $\$$ ) } \\
\hline REVENUES & 678.68 & 749.97 & 905.18 & 1066.32 & 1341.68 & 1551.31 & 1928.70 & 2159.36 & 2449.63 \\
\hline TOTAL PRODUCTION EXPENSE & 263.05 & 309.02 & 399.40 & 475.11 & 657.36 & 779.37 & 980.53 & 1112.48 & 1322.43 \\
\hline OTHER EXPENSES AND TAXES & 280.18 & 306.38 & 356.43 & 406.39 & 480.90 & 535.57 & 642.77 & 711.65 & 800.07 \\
\hline OPERATING INCOME & 135.45 & 134.57 & 149.35 & 184.82 & 203.42 & 236.37 & 305.41 & 335.23 & 327.13 \\
\hline INTEREST EXPENSE & 58.24 & 59.03 & 66.37 & 81.52 & 88.22 & 102.99 & 129.93 & 140.71 & 137.00 \\
\hline NET I NCOME & 77.21 & 75.54 & 82.98 & 103.29 & 115.20 & 133.38 & 175.47 & 194.51 & 190.13 \\
\hline TOTAL ASSETS & 1204.66 & 1223.16 & 1398.51 & 1748.14 & 1909.49 & 2262.39 & 2905.70 & 3163.09 & 3074.55 \\
\hline RETURN ON EQUITY (\%) & 12.9 & 12.4 & 12.4 & 12.4 & 12.3 & 12.4 & 12.4 & 12.4 & 12.3 \\
\hline PERCENT OF CONSTRUCTION & & & & & & & & & \\
\hline INTERNALLY FUNDED (\%): & 100 & 100 & 67 & 61 & 100 & 59 & 76 & 100 & 100 \\
\hline INTEREST COVERAGE & & & & & & & & & \\
\hline BEFORE TAX RATIO & 3.007 & 2.936 & 2.890 & 2.916 & 2.976 & 2.960 & 3.045 & 3.093 & 3.100 \\
\hline
\end{tabular}

SUMMARY STATISTICS

8076 Present value of revenues, 1990-2010 (Million 1985-\$)

10706 Present value of revenues, 1990-2030 (Million 1985-\$)

15 Present value of customer cost for dsm, 1990-2010 (Million 1985-\$)

2537 Present value of environmental cost, 1990-2010 (Million 1985-\$)

5.56 Average electricity price (1985-c/kWh)

957 Average electric bill (1985-\$/customer)

0.02 Average reserve margin

SUMMARY OF DECISIONS MADE DURING EXERCISE

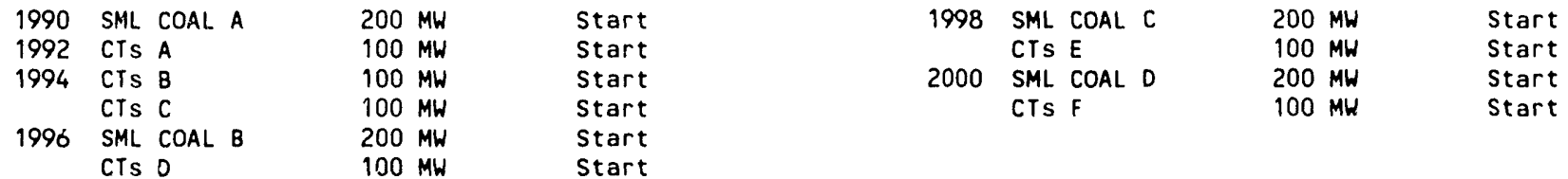


Table A2. Summary report for case shown in Table 7, DSM and supply plan for base utility

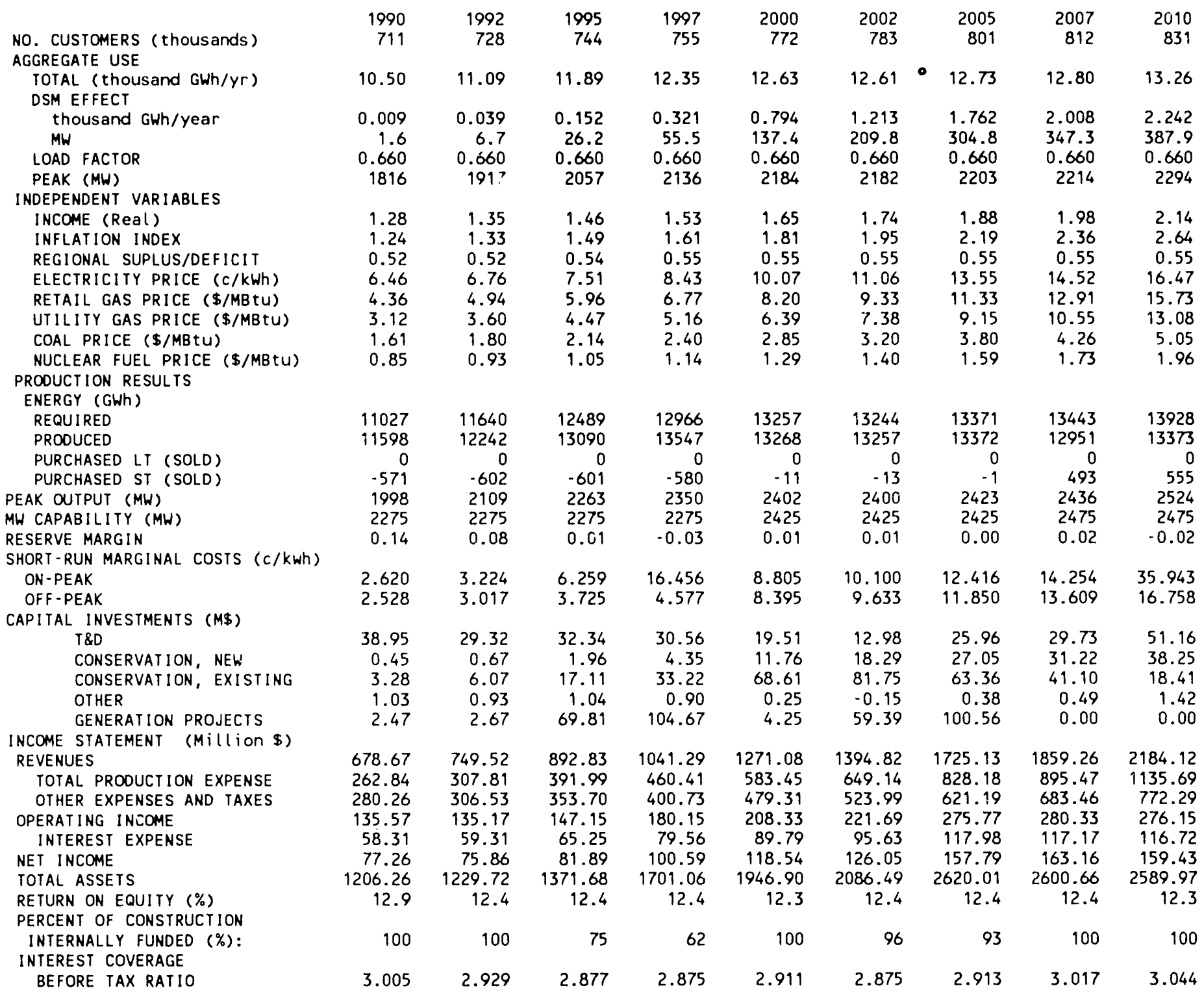

SUMMARY STATISTICS

$\begin{array}{ll}7624 & \text { Present value of revenues, } 1990-2010 \text { (Million 1985-\$) } \\ 9938 & \text { Present value of revenues, 1990-2030 (Million 1985-\$) } \\ 0 & \text { Present value of customer cost for dsm, 1990-2010 (Million 1985-\$) } \\ 2480 & \text { Present value of environmental cost, 1990-2010 (Million 1985-\$) } \\ 5.60 & \text { Average electricity price }(1985-\mathrm{c} / \mathrm{kWh}) \\ 889 & \text { Average electric bill (1985-\$/customer) } \\ 0.02 & \text { Average reserve margin } \\ 12.4 & \text { Average return on equity } \\ 0.0 & \text { Average difference between cost of equity and return on equity }\end{array}$

SUMMARY OF DECISIONS MADE DURING EXERCISE

$\begin{array}{llccc}1990 & \text { SML COAL A } & 200 \mathrm{MW} & & \text { Start } \\ & \text { Existing DSM } & \$ 50 / \text { part } & 1.0 & 4.5 \mathrm{c} / \mathrm{kWh} \\ & \text { NeW DSM } & \$ 100 / \text { part } & 1.0 & 4.5 \mathrm{c} / \mathrm{kWh} \\ 1994 & \text { CTS A } & 100 \mathrm{MW} & & \text { Start }\end{array}$

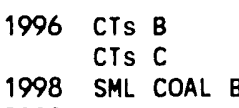

2000 CTS D

$\begin{array}{ll}100 \mathrm{MW} & \text { Start } \\ 100 \mathrm{MW} & \text { Start } \\ 200 \mathrm{MW} & \text { Start } \\ 100 \mathrm{MW} & \text { Start }\end{array}$


Table A3. Summary report for case shown in Table 11, supply-only plan for surplus utility

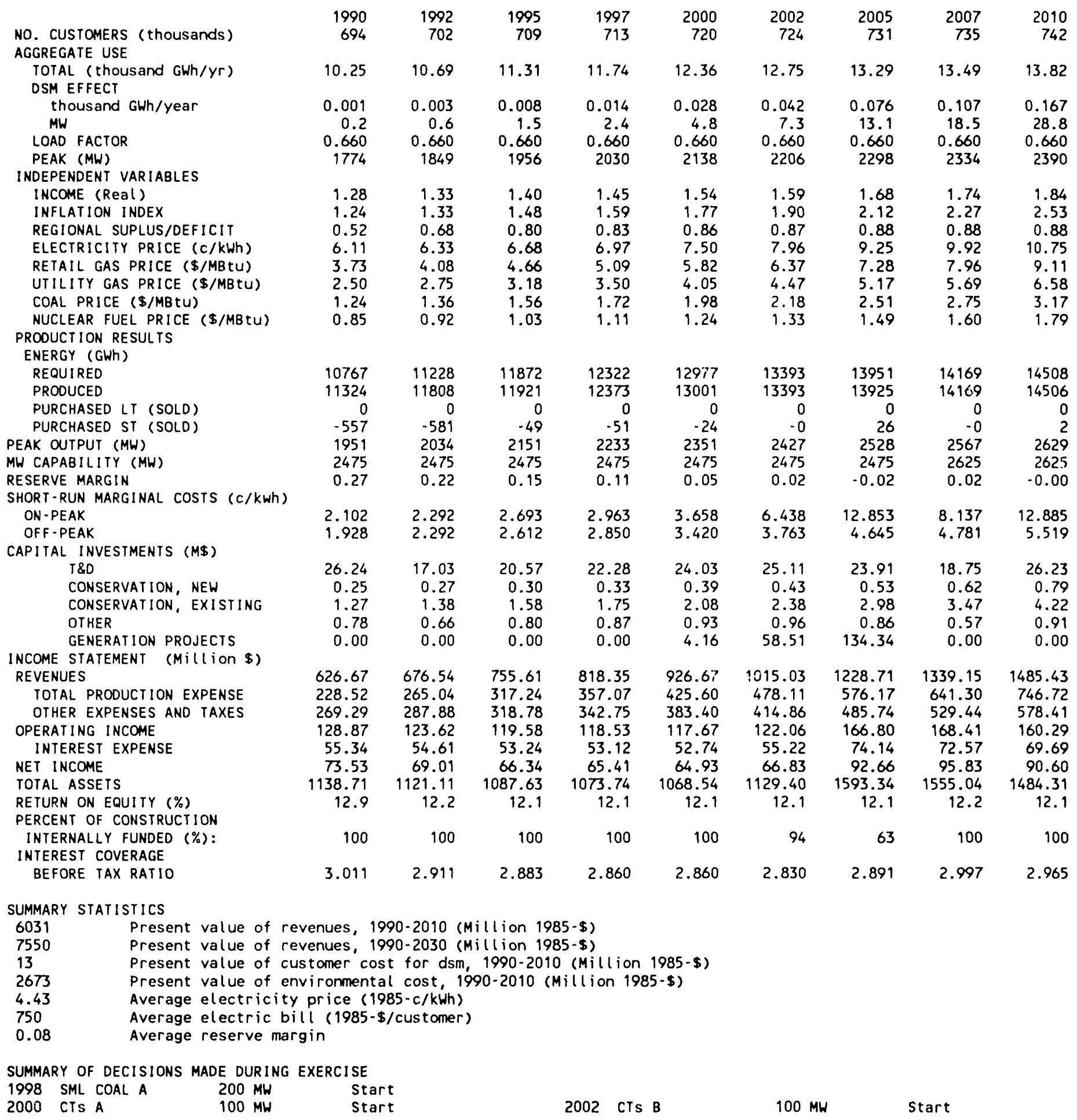


Table A4. Summary report for case shown in Table 12, DSM and supply plan for surplus utility

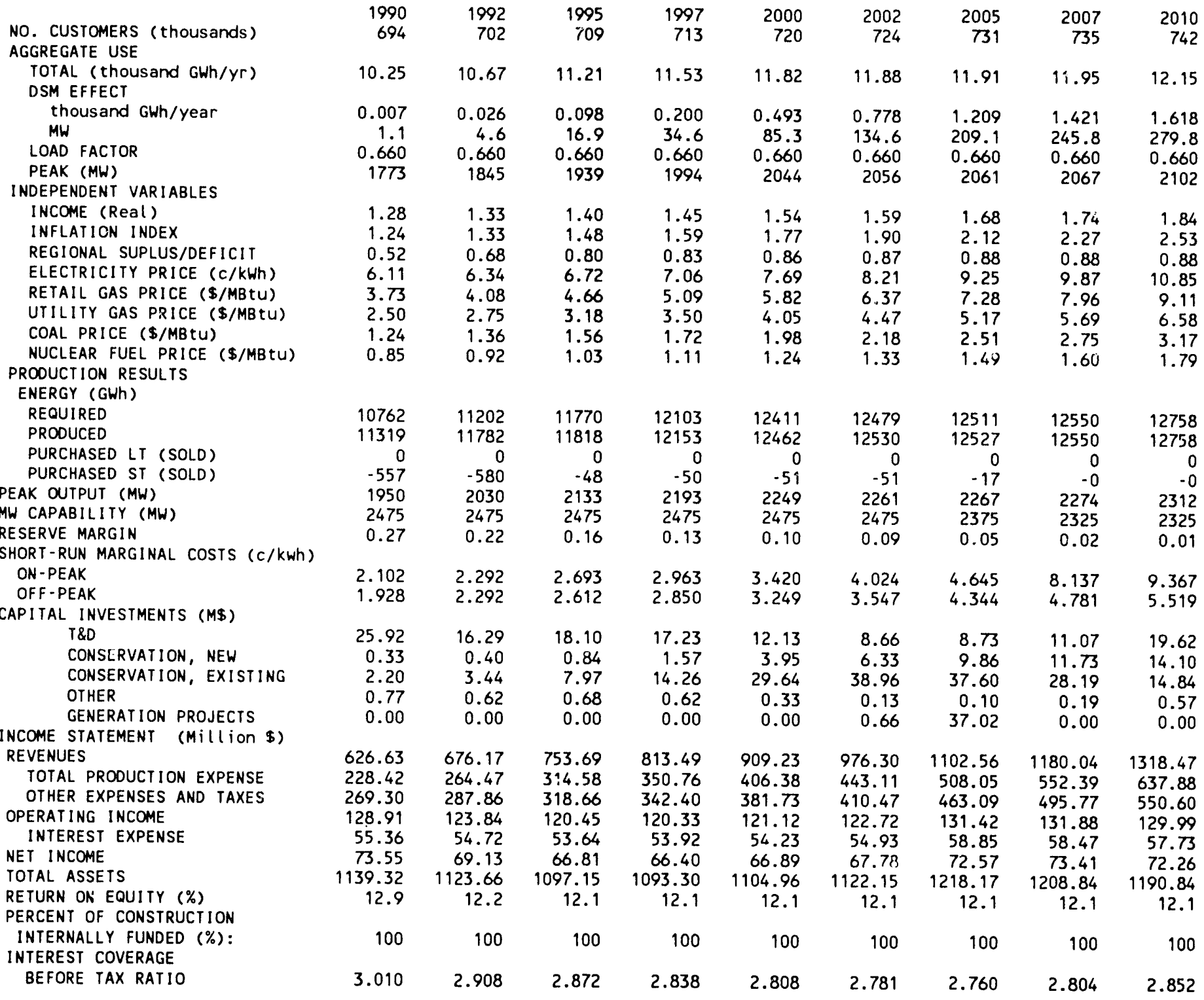

SUMMARY STATISTICS

5817 Present value of revenues, 1990-2010 (Million 1985-\$)

7113 Present value of revenues, 1990-2030 (Million 1985-\$)

0 Present value of customer cost for dsm, 1990-2010 (Million 1985-\$)

2619 Present value of environmental cost, 1990-2010 (Million 1985-\$)

4.47 Average electricity price $(1985-\mathrm{c} / \mathrm{kWh})$

715 Average electric bill (1985-\$/customer)

0.11 Average reserve margin

SUMMARY OF DECISIONS MADE DURING EXERCISE

1990 Existing DSM \$ 50/part $1.03 .0 \mathrm{c} / \mathrm{kWh}$

NeW DSM \$ $100 /$ part $1.03 .0 \mathrm{c} / \mathrm{kWh}$

2002 CTs A

$100 \mathrm{MW}$

Start 
Table A5. Surmary report for case shown in Table 13, supply-only plan for deficit utility

\begin{tabular}{|c|c|c|c|c|c|c|c|c|c|}
\hline $\begin{array}{l}\text { NO. CUSTOMERS (thousands) } \\
\text { AGGREGATE USE }\end{array}$ & $\begin{array}{r}1990 \\
710\end{array}$ & $\begin{array}{r}1992 \\
731\end{array}$ & $\begin{array}{r}1995 \\
761\end{array}$ & $\begin{array}{r}1997 \\
776\end{array}$ & $\begin{array}{r}2000 \\
796\end{array}$ & $\begin{array}{r}2002 \\
810\end{array}$ & $\begin{array}{r}2005 \\
831\end{array}$ & $\begin{array}{r}2007 \\
845\end{array}$ & $\begin{array}{r}2010 \\
867\end{array}$ \\
\hline $\begin{array}{l}\text { TOTAL (thousand GWh/Yr) } \\
\text { DSM EFFECT }\end{array}$ & 10.40 & 11.04 & 12.28 & 13.00 & 13.78 & 14.30 & 15.23 & 15.73 & 16.72 \\
\hline thousand GWh/year & 0.001 & 0.004 & 0.009 & 0.015 & 0.030 & 0.045 & 0.080 & 0.114 & 0.180 \\
\hline MW & 0.2 & 0.6 & 1.6 & 2.6 & 5.2 & 7.8 & 13.9 & 19.7 & 31.2 \\
\hline LOAD FACTOR & 0.660 & 0.660 & 0.660 & 0.660 & 0.660 & 0.660 & 0.660 & 0.660 & 0.660 \\
\hline PEAK (MW) & 1799 & 1910 & 2123 & 2249 & 2383 & 2474 & 2635 & 2721 & 2892 \\
\hline \multicolumn{10}{|l|}{ INDEPENDENT VARIABLES } \\
\hline INCOME (Real) & 1.27 & 1.40 & 1.59 & 1.69 & 1.85 & 1.96 & 2.14 & 2.27 & 2.48 \\
\hline INFLATION INDEX & 1.23 & 1.34 & 1.51 & 1.64 & $1.8 / 4$ & 1.99 & 2.24 & 2.42 & 2.73 \\
\hline REGIONAL SUPLUS/DEFICIT & 0.37 & 0.35 & 0.34 & 0.36 & 0.37 & 0.37 & 0.38 & 0.38 & 0.38 \\
\hline ELECTRICITY PRICE (c/kWh) & 6.90 & 7.34 & 8.49 & 9.83 & 11.57 & 13.00 & 15.65 & 17.01 & 18.23 \\
\hline RETAIL GAS PRICE (\$/MBtU) & 5.49 & 6.18 & 7.67 & 8.84 & 10.95 & 12.65 & 15.73 & 18.20 & 22.69 \\
\hline UTILITY GAS PRICE ( $\$ / M B T U)$ & 4.26 & 4.84 & 6.16 & 7.20 & 9.11 & 10.66 & 13.49 & 15.78 & 19.97 \\
\hline COAL PRICE (\$/MBTU) & 1.96 & 2.19 & 2.57 & 2.86 & 3.46 & 3.92 & 4.73 & 5.37 & 6.48 \\
\hline NUCLEAR FUEL PRICE ( $\$ / M B t U)$ & 0.89 & 0.99 & 1.16 & 1.28 & 1.49 & 1.65 & 1.93 & 2.14 & 2.49 \\
\hline \multirow{2}{*}{\multicolumn{10}{|c|}{$\begin{array}{l}\text { PRODUCTION RESULTS } \\
\text { ENERGY (GWh) }\end{array}$}} \\
\hline & & & & & & & & & \\
\hline REQUIRED & 10918 & 11594 & 12890 & 13652 & 14469 & 15018 & 15994 & 16517 & 17555 \\
\hline PRODUCED & 12048 & 12748 & 13030 & 13652 & 13780 & 14173 & 15272 & 16621 & 17278 \\
\hline PURCHASED LT (SOLD) & 0 & 0 & 0 & 0 & 0 & 0 & 0 & 0 & 0 \\
\hline PURCHASED ST (SOLD) & -1130 & -1154 & -140 & -0 & 689 & 845 & 721 & -104 & 277 \\
\hline PEAK OUTPUT (MW) & 1978 & 2101 & 2336 & 2474 & 2622 & 2721 & 2898 & 2993 & 3181 \\
\hline MW CAPABILITY (MW) & 2275 & 2275 & 2375 & 2475 & 2625 & 2625 & 2775 & 2975 & 3075 \\
\hline RESERVE MARGIN & 0.15 & 0.08 & 0.02 & 0.00 & 0.00 & -0.04 & -0.04 & -0.01 & -0.03 \\
\hline \multicolumn{10}{|l|}{ SHORT-RUN MARGINAL COSTS (c/kwh) } \\
\hline ON-PEAK & 2.932 & 4.276 & 8.377 & 9.739 & 12.220 & 31.468 & 38.282 & 21.874 & 53.637 \\
\hline OFF-PEAK & 2.773 & 3.252 & 3.791 & 6.318 & 7.967 & 11.439 & 9.755 & 7.506 & 12.649 \\
\hline \multicolumn{10}{|l|}{ CAPITAL INVESTMENTS (M\$) } \\
\hline$T \& D$ & 36.40 & 44.68 & 49.56 & 43.44 & 40.87 & 50.66 & 63.02 & 54.41 & 86.98 \\
\hline CONSERVATION, NEW & 0.25 & 0.28 & 0.32 & 0.35 & 0.42 & 0.48 & 0.62 & 0.76 & 1.04 \\
\hline CONSERVATION, EXISTING & 1.26 & 1.39 & 1.62 & 1.81 & 2.18 & 2.50 & 3.16 & 3.71 & 4.58 \\
\hline OTHER & 0.93 & 1.24 & 1.59 & 1.41 & 1.16 & 1.57 & 2.04 & 1.49 & 2.94 \\
\hline GENERATION PROJECTS & 9.06 & 41.33 & 200.12 & 336.46 & 198.91 & 334.66 & 510.89 & 16.97 & 0.00 \\
\hline \multicolumn{10}{|l|}{ INCOME STATEMENT (Million \$) } \\
\hline REVENUES & 717.82 & 810.07 & 1041.87 & 1278.23 & 1594.02 & 1859.48 & 2384.51 & 2675.76 & 3048.07 \\
\hline TOTAL PROOUCTION EXPENSE & 288.31 & 340.29 & 455.53 & 550.43 & 697.20 & 837.72 & 1064.24 & 1204.60 & 1518.63 \\
\hline OTHER EXPENSES AND TAXES & 284.32 & 317.26 & 389.82 & 456.92 & 568.05 & 641.66 & 787.61 & 907.60 & 995.26 \\
\hline OPERATING INCOME & 145.19 & 152.51 & 196.52 & 270.88 & 328.77 & 380.10 & 532.66 & 563.56 & 534.18 \\
\hline INTEREST EXPENSE & 62.30 & 65.88 & 86.91 & 119.10 & 139.68 & 162.81 & 227.12 & 231.43 & 220.37 \\
\hline NET INCOME & 82.88 & 86.63 & 109.61 & 151.78 & 189.09 & 217.30 & 305.54 & 332.13 & 313.81 \\
\hline TOTAL ASSETS & 1299.92 & 1381.05 & 1872.09 & 2616.62 & 3100.90 & 3645.08 & 5158.33 & 5259.77 & 4999.59 \\
\hline RETURN ON EQUITY (\%) & 12.8 & 12.8 & 12.5 & 12.5 & 12.5 & 12.5 & 12.5 & 12.5 & 12.5 \\
\hline \multicolumn{10}{|l|}{ PERCENT OF CONSTRUCTION } \\
\hline INTERNALLY FUNDED $(\%)$ : & 100 & 100 & 44 & 36 & 84 & 59 & 50 & 100 & 100 \\
\hline \multicolumn{10}{|l|}{ INTEREST COVERAGE } \\
\hline BEFORE TAX RATIO & 3.014 & 2.989 & 2.908 & 2.928 & 3.049 & 3.021 & 3.037 & 3.173 & 3.156 \\
\hline
\end{tabular}

SUMMARY STATISTICS

9378 Present value of revenues, 1990-2010 (Million 1985-\$)

12645 Present value of revenues, 1990-2030 (Million 1985-\$)

15 Present value of customer cost for dsm, 1990-2010 (Million 1985-\$)

2675 Present value of environmental cost, 1990-2010 (Million 1985-\$)

6.24 Average electricity price $(1985-\mathrm{c} / \mathrm{kWh})$

1078 Average electric bill (1985-\$/customer)

0.02 Average reserve margin

SUMMARY OF DECISIONS MADE DURING EXERCISE

$\begin{array}{llll}1990 & \text { BIG COAL A } & 500 \mathrm{MW} & \text { Start } \\ & \text { CTS A } & 100 \mathrm{MW} & \text { Start } \\ 1992 & \text { CTS B } & 100 \mathrm{MW} & \text { Start } \\ 1994 & \text { SML COAL A } & 200 \mathrm{MW} & \text { Start } \\ & \text { CTS C } & 100 \mathrm{MW} & \text { Start }\end{array}$

1996 SML COAL B

1998 BIG COAL B SML COAL C
$200 \mathrm{MW}$

$500 \mathrm{MW}$

$200 \mathrm{MW}$
Start

Start

Start 
Table A6. Summary report for case shown in Table 14, DSM and supply plan for deficit utility

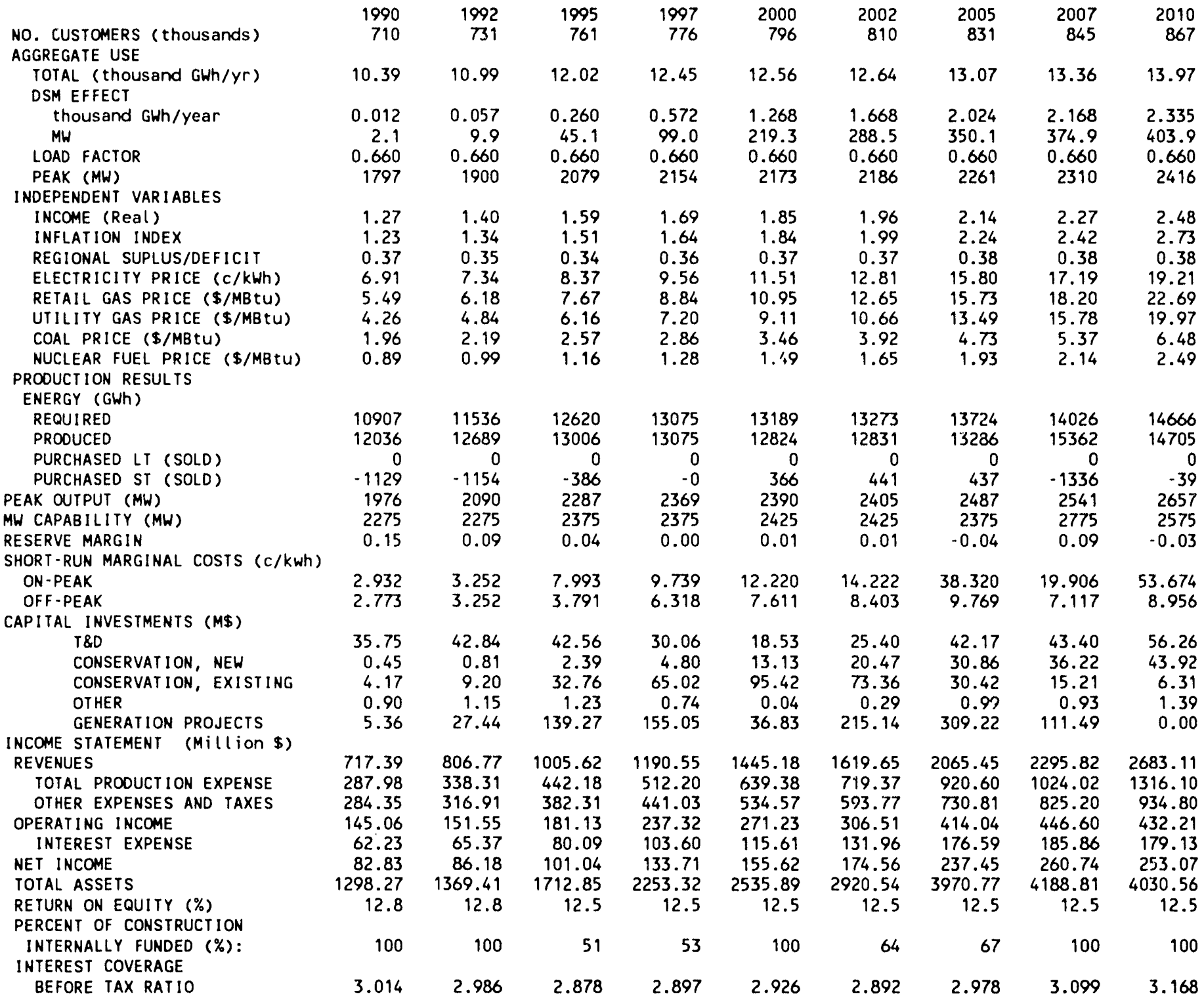

SUMMARY STATISTICS

8664 Present value of revenues, 1990-2010 (Million 1985-\$)

11512 Present value of revenues, 1990-2030 (Million 1985-\$)

0 Present value of customer cost for dsm, 1990-2010 (Million 1985-\$)

2612 Present value of environmental cost, 1990-2010 (Million 1985-\$)

6.28 Average electricity price (1985-c/kWh)

985 Average electric bill (1985-\$/customer)

0.03

Average reserve margin

SUMMARY OF DECISIONS MADE DURING EXERCISE

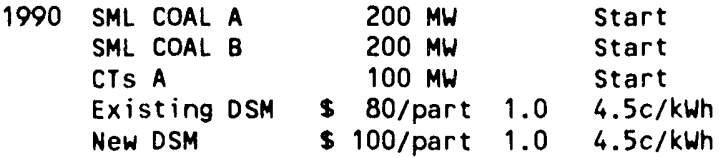

1996 SML COAL C CTS B

1998 SML COAL D SML COAL E 2000 SML COAL F
$200 \mathrm{MW}$
$100 \mathrm{MW}$
$200 \mathrm{MW}$
$200 \mathrm{MW}$
$200 \mathrm{MW}$

Start

Start

Start

Start

Start 


\section{APPENDIX B. DESCRIPTION OF THE DIAMOND MODEL}

A new utility planning model, DIAMOND (Decision Impact Assessment Model), developed at Oak Ridge National Laboratory, was used to analyze the effects of alternative demand and supply res urces on the utility's revenues and prices. This Appendix summarizes the key features of the SIMULATION and DECISION submodels; see Gettings, Hirst, and Yourstone (1991) for additional detail on the model.

\section{SIMULATION}

DIAMOND's SIMULATION submodel includes five elements that simulate the annual operation and finances of the utility. The five elements, in order of their operation, are:

1. LOADS, which calculates the electricity demand (in GWH and peak MW) to be served that year. Loads are reduced each year by DSM programs initiated or modified in DECISION.

2. PRODUCTION, which dispatches the utility's power plants and buys and sells wholesale power (both through long-term contracts and one-year spot-market arrangements) to meet the peak demands and annual energy requirements determined in LOADS.

3. INVESTMENT, which controls the utility's construction program. The capital expenditures for new power plants, transmission and distribution plant, and other assets are calculated here.

4. FINANCES, which computes the utility's annual income statement and balance sheet and other financial information.

5. REGULATION, which determines the timing and extent of rate increases (which go) into effect the following year).

$\underline{\text { Loads }}$

This portion of SIMULATION computes annual electricity use (GWh) and peak demand (MW) for each year. Electricity use is calculated separately for new and existing customers as the product of the number of customers and electricity use per customer. Existing customers are defined as those still in existence that were in place as of the initial year (1985 in this case). This submodel computes the number of new customers each year, based on local economic growth. The number of existing customers retired is based on a user-specified demolition rate. 
Electricity use per existing customer is computed as a function of electricity price, service-area income, and natural gas price, given the elasticities provided by the user. Similarly, electricity use per new customer is computed as a function of the same explanatory variables, but with higher elasticities. Thus, the model includes feedback loops from the price of electricity (a function of generating mix, fuel prices, and DSM programs) to electricity use.

Peak demand is determined on the basis of a user-specified load factor ( $66 \%$ at the customer level, yielding $63 \%$ at the busbar) and annual sales. Thus, system load factor is invariant with time.

\section{Production}

This part of SIMULATION dispatches power plants to meet the annual and peak demands for electricity. The program first increases the peak demand and annual sales figures from LOADS to reflect system energy and demand losses (5 and 10\% here); these loss factors are invariant with time. The resultant (higher) values represent the capacity and generation required from the power-supply system.

DIAMOND uses a two-part annual load-duration curve (Fig. 12). One part represents peak loads (e.g., the amount of power consumed during the top 500 hours of the year), and the remainder is baseload (demanded during the full 8760 hours of the year).

LOAD (MW)

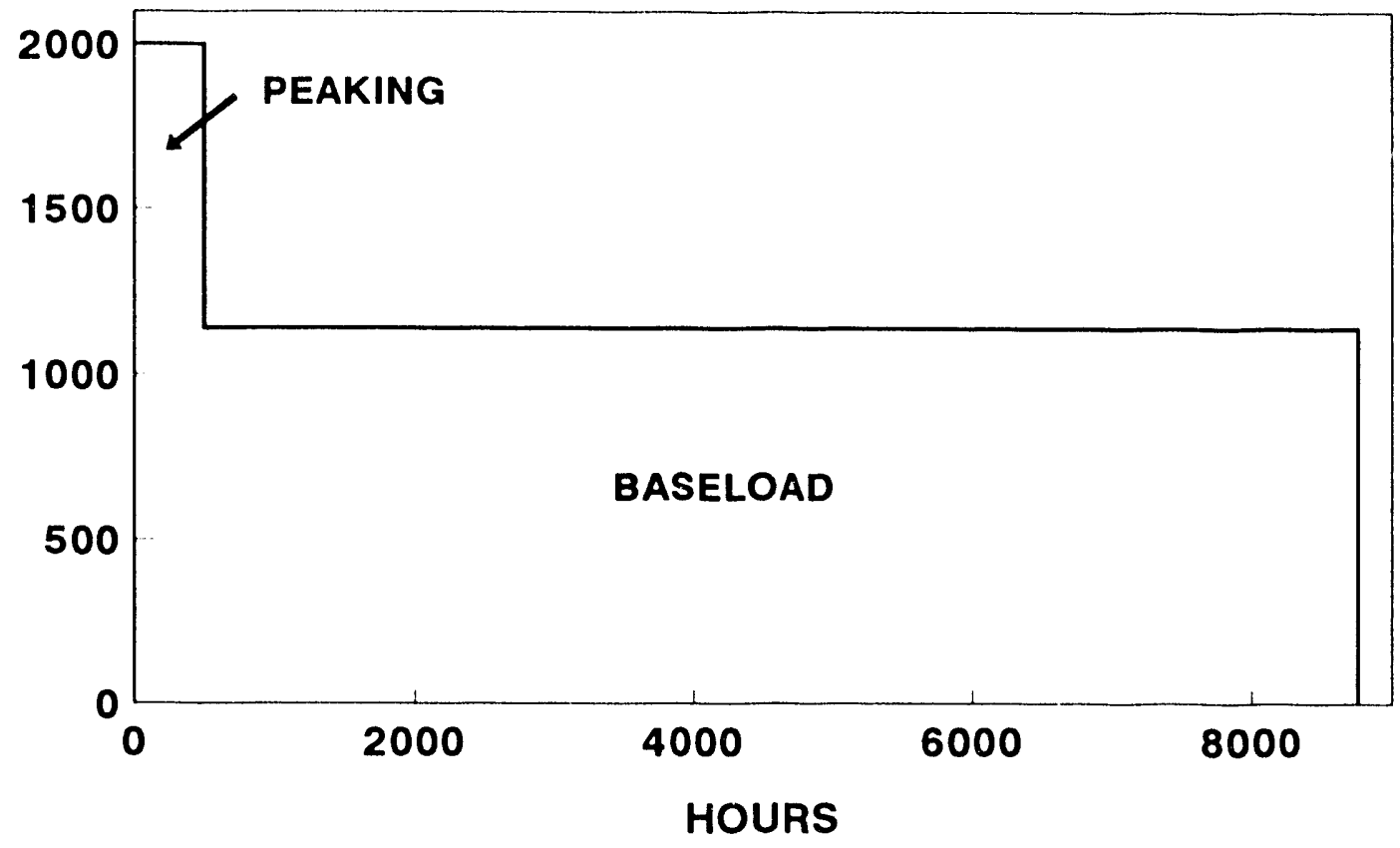

Fig. 12. Simple two-part load-duration curve used in simulation model to dispatch baseload and peaking power plants. 
The utility's power plants are dispatched on the basis of economics, with the least-cost units (in terms of variable $c / \mathrm{kWh}$ ) dispatched first. The model first dispatches capacity to meet demand during the peak period and then uses the remaining capacity to provide baseload power.

The model allows for short-term (one-year) energy and capacity sales or purchases with neighboring utilities. These spot prices depend on the region's surplus/deficit situation, which is a function of growth rates in the regional economy and in natural-gas prices. When the region has a large surplus, short-term purchase prices are slightly above the variable operating costs of a coal plant or a combined-cycle gas-fired combustion turbine, for base and peaking power respectively. When the region has a large deficit, short-term prices are above the embedded (both operating and levelized capital) costs of these two types of power plants. The price at which the utility can sell is set lower than the price at which it can buy to reflect transaction and transmission costs. Also, the amount of electricity the utility can sell short-term is limited to a user-specified fraction of native energy requirements. Similarly, the amount of electricity the utility can buy at these prices is limited to a value selected by the user. Beyond that amount, the price is much higher to reflect the cost of outages.

SIMULATION calculates whether it is cheaper to buy from other utilities than to generate with the utility's own plants. Alternatively, it might determine that generating excess power and selling it to neighboring utilities is cheaper.

PRODUCTION calculates variable costs for all utility-owned power plants and longterm contracts, the GWh output from each plant, and the contribution from each plant to peak demand. It computes a load/resource balance showing the amount of generation required and produced each year, short-and long-term purchases and sales, and the utility's reserve margin. It also computes short-run marginal costs for the peak and haseload periods and the costs to operate the production system, including operating and maintenance expenses, fuel expenses, and power-purchase expenses (or receipts), all of which are used in FINANCES to calculate the financial condition of the utility.

\section{Investment}

This submodel calculates and accumulates the annual capital costs, tax and book depreciation expenses, and deferred tax expense for all assets. Thus, this submodel calculates the costs for:

Constructing new power plants

Transmission and distribution expansions

DSM programs

Other assets (e.g., trucks and computers)

Unamortized assets (abandoned plants)

Accumulated deferred income taxes (normalization of timing differences between book and tax depreciation) 
The annual capital expenditures for transmission and distribution and for other assets are calculated as follows:

$$
\begin{array}{r}
\text { Capital cost }=\left[a\left(\Delta_{\text {customers }}\right)+b\left(\Delta_{\text {energy production }}\right)\right. \\
\left.+c\left(\Delta_{\text {peak load }}\right)\right] \text { Inflation index }
\end{array}
$$

where a, b, and c are user-specified constants. $\Delta$ refers to the year-to-year changes in the three variables. The three coefficients are different for transmission and distribution and other capital costs and are user inputs. These capital costs ensure that changes in loads affect capital and operating costs appropriately. For example, expanding the utility's DSM programs will reduce growth in both energy and peak demand, which in turn reduces capital requirements for transmission and distribution. Economic growth, on the other hand, leads to growth in the number of new customers as well as to more rapid growth in both energy and peak demand, increasing capital expenditures on transmission and distribution.

The costs of DSM programs are based on the user's decisions concerning marketing costs and financial incentives and by the number of new and existing customers computed in LOADS.

\section{Finances}

This submodel determines the financial implications of decisions, power-system operations, and other utility activities. It calculates the annual income statement and balance sheet for the utility as well as key financial ratios. It also computes the equity and debt financing (stocks and long-term bonds) required to operate the utility.

Revenues are equal to the product of electricity sales (GWh) times average price (from REGULATION at the end of the puior year). Expenses include power production costs; nonproduction expenses; nonproduction expenses, other; book depreciation; and taxes.

Production expenses include fuel, net purchased power, and operations and maintenance. Nonproduction expenses include customer and administrative costs, determined by

$$
[(a \times \text { Customers })+(b \times \text { Peak load })+(c \times \text { GWh sales })] \times \text { Inflation index , }
$$

where $a, b$, and $c$ are constants.

Other nonproduction expenses reflect amortization of abandoned power plants and mothballing costs. Book depreciation includes plants in service and DSM program costs. All assets are depreciated on a straight-line hasis for book depreciation. 
Revenue-sensitive taxes are the product of a user-specified tax rate and revenues. Deferred federal income taxes are calculated in INVESTMENT as the difference between book and tax depreciation of plant in service.

Operating income is the difference between revenues and expenses. Operating income minus interest expenses and extraordinary items yields net income. This is the return to common stockholders, which is split between dividends and retained earnings. The fraction of net income paid as dividends is specified by the user as the dividend-payout ratio.

The balance sheet includes gross plant (which consists of production, transmission and distribution, DSM, and other assets), accumulated depreciation, construction-work-inprogress, current assets, accumulated deferred income tax, and unamortized assets balances.

Long-term debt is equal to total assets times the user-specified target debt fraction. Common equity is equal to total assets times (1 - target debt fraction). Thus, the target capital structure of the utility is always maintained.

\section{Regulation}

This submodel simulates regulatory treatment of the utility's rates and rate base. Prices are adjusted so that, on a forecast basis, the return on equity matches the targeted return. Because the forecast amounts and actual results will almost always differ, the actual return and cost of equity will rarely be equal. The user specifies the minimum number of years between "rate cases" and the minimum percentage changes in prices allowed before a rate case occurs. These inputs simulate the delays associated with regulatory lag.

If the actual return on equity for the previous year differs from the allowed return, REGULATION calculates the projected change in electricity price needed to equate actual and allowed return. The total assets of the utility for the coming year are estimated from the changes in assets during the past five years, and those total assets are multiplied by the current cost of capital to give the utility's allowed operating income. The price of electricity is then adjusted so that the operating income will be achieved given the loads and expenses expected for the coming year. The new electricity price goes into effect at the beginning of the following year.

Alternatively, the user can implement a revenue-adjustment mechanism that ensures that the utility, each year, earns its authorized return. This option is used in the present analyses to avoid problems associated with earnings shortfalls caused by DSM programs and is similar to the mechanism used in California (Marnay and Comnes 1990).

\section{DECISION}

The DECISION part of DIAMOND allows users to choose among various resources to meet future energy and load requirements: 
1. Construction of new generating facilities (e.g., large or small coal plants, nuclear plants, combustion turbines, combined-cycle units, and hydro), with the choices established before the model is run

2. Purchase of capacity or energy from other utilities under long-term contracts

3. Conservation and load-management programs that affect annual electricity use and peak demands for new and existing customers

These choices are described in Gettings, Hirst, and Yourstone (1991). 


\section{INTERNAL DISTRIBUTION}

1. V. D. Baxter

2. L. Berry

3. D. S. Bjornstad

4. R. B. Braid

5. M. A. Brown

6. R. S. Carlsmith

7. R. Cantor

8. F. C. Chen

9. J. Christian

10. G. Courville

11. S. J. Dale

12. P. D. Fairchild

13. W. Fulkerson

14. M. B. Gettings

15. C. W. Hagan

16. L. J. Hill

17. E. Hillsman

18. E. Hirst

19. P. J. Hughes

20. C. R. Kerley

21. J. O. Kolb

22. M. A. Kuliasha

23. R. Lee

24. P. Leiby
25. J. M. MacDonald

26. L. ''. McCold

27. V. C. Mei

28. W. R. Mixon

29. C. H. Petrich

30. S. Purucker

31. S. Rayner

32. J. H. Reed

33. D. E. Reichle

34. D. T. Rizy

35. M. Schweitzer

36. R. B. Shelton

37. G. G. Stevenson

38. J. N. Stone

39. J. Van Dyke

40. J. M. Veigel (ORAU)

41. D. B. Waddle

42. D. L. White

43. T. J. Wilbanks

44. ORNL Patent office

45. Central Research Library

46. Document Reference Section

47. Laboratory Records (RC)

48-50. Laboratory Records Dept.

\section{EXTERNAL DISTRIBUTION}

51. Bruce G. Buchanan, Computer Science Department, University of Pittsburgh, 206 Mineral Industries Building, Pittsburgh, PA 15260

52. Allan Hirsch, Vice President, Environmental Sciences, and Director, Washington Operations, 5109 Leesburg Pike, Suite 414, Falls Church, VA 22041

53. Martin Williams, Professor, Department of Economics, Northern Illinois University, DeKalb, IL 60115

54. Helen Ingram, Director, Udall Center for Studies in Public Policy, University of Arizona, 803/811 East First Street, Tucson, AZ 85719

55. Calvin MacCracken, President, Calmac Manufacturing Corporation, 101 West Sheffield Avenue, P. O. Box 710, Englewood, NJ 07631

56.-65. OSTI, U. S. Department of Energy, P. O. Box 62, Oak Ridge, Tennessee 37831

66. Office of Assistant Manager for Energy Research and Development, DOE/ORO, P. O. Box 2001 Oak Ridge, TN 37831-8600

67.-800. External Energy Efficiency and Renewables Section Distribution Mailing List and extra copies to E.M. Schorn, 4500N, H-19A 


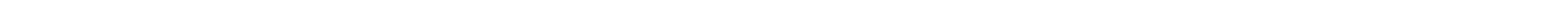


